\title{
Arctic Ocean Freshwater Changes over the Past 100 Years and Their Causes
}

\author{
I. V. Polyakov, * V. A. Alexeev,* G. I. Belchansky, ${ }^{+}$I. A. Dmitrenko,* V. V. Ivanov,* S. A. Kirillov, \# \\ A. A. Korablev,\# M. Steele, ${ }^{@}$ L. A. Timokhov, ${ }^{\#}$ and I. Yashayaev\& \\ *International Arctic Research Center, University of Alaska Fairbanks, Fairbanks, Alaska \\ + Institute of Ecology RAN, Moscow, Russia \\ \# Arctic and Antarctic Research Institute, St. Petersburg, Russia \\ @ Polar Science Center, Applied Physics Laboratory, University of Washington, Seattle, Washington \\ \& Ocean Circulation Section, Ocean Sciences Division, Bedford Institute of Oceanography, Dartmouth, Nova Scotia, Canada
}

(Manuscript received 25 October 2006, in final form 5 March 2007)

\begin{abstract}
Recent observations show dramatic changes of the Arctic atmosphere-ice-ocean system. Here the authors demonstrate, through the analysis of a vast collection of previously unsynthesized observational data, that over the twentieth century the central Arctic Ocean became increasingly saltier with a rate of freshwater loss of $239 \pm 270 \mathrm{~km}^{3} \mathrm{decade}^{-1}$. In contrast, long-term (1920-2003) freshwater content (FWC) trends over the Siberian shelf show a general freshening tendency with a rate of $29 \pm 50 \mathrm{~km}^{3} \mathrm{decade}^{-1}$. These FWC trends are modulated by strong multidecadal variability with sustained and widespread patterns. Associated with this variability, the FWC record shows two periods in the 1920s-30s and in recent decades when the central Arctic Ocean was saltier, and two periods in the earlier century and in the 1940s-70s when it was fresher. The current analysis of potential causes for the recent central Arctic Ocean salinification suggests that the FWC anomalies generated on Arctic shelves (including anomalies resulting from river discharge inputs) and those caused by net atmospheric precipitation were too small to trigger long-term FWC variations in the central Arctic Ocean; to the contrary, they tend to moderate the observed long-term centralbasin FWC changes. Variability of the intermediate Atlantic Water did not have apparent impact on changes of the upper-Arctic Ocean water masses. The authors' estimates suggest that ice production and sustained draining of freshwater from the Arctic Ocean in response to winds are the key contributors to the salinification of the upper Arctic Ocean over recent decades. Strength of the export of Arctic ice and water controls the supply of Arctic freshwater to subpolar basins while the intensity of the Arctic Ocean FWC anomalies is of less importance. Observational data demonstrate striking coherent long-term variations of the key Arctic climate parameters and strong coupling of long-term changes in the Arctic-North Atlantic climate system. Finally, since the high-latitude freshwater plays a crucial role in establishing and regulating global thermohaline circulation, the long-term variations of the freshwater content discussed here should be considered when assessing climate change and variability.
\end{abstract}

\section{Introduction}

Exchanges between the Arctic and North Atlantic Oceans have a profound influence on the circulation and thermodynamics of each basin (Aagaard and Carmack 1994). The Arctic Ocean is one of the major source regions for the surface waters of the subpolar seas, in which weak stratification leads to deep convection, a key contributor to the global thermohaline circulation (Dickson et al. 2000). Indeed, modeling results

Corresponding author address: Igor Polyakov, International Arctic Research Center, University of Alaska Fairbanks, 930 Koyukuk Dr., Fairbanks, AK 99775.

E-mail: igor@iarc.uaf.edu provided evidence that the North Atlantic thermohaline circulation may be strengthened by $10 \%-20 \%$ in response to a decrease of ice outflow of $800 \mathrm{~km}^{3}$ (Mauritzen and Häkkinen 1997).

How much of high-latitude ice-freshwater export is driven by change in Arctic Ocean freshwater budget due to anomalous river runoff and precipitation? What is the role of ice melt/freezing and isopycnal heaving? How much does wind-driven circulation affect the Arctic Ocean's freshwater content (FWC)? Several studies address some of these and other questions related to changes in the FWC of the Polar Basin (e.g., Aagaard and Carmack 1989; Proshutinsky et al. 2002; Häkkinen and Proshutinsky 2004; Swift et al. 2005; Peterson et al. 2006; Steele and Ermold 2007). In this study, through

DOI: 10.1175/2007JCLI1748.1 


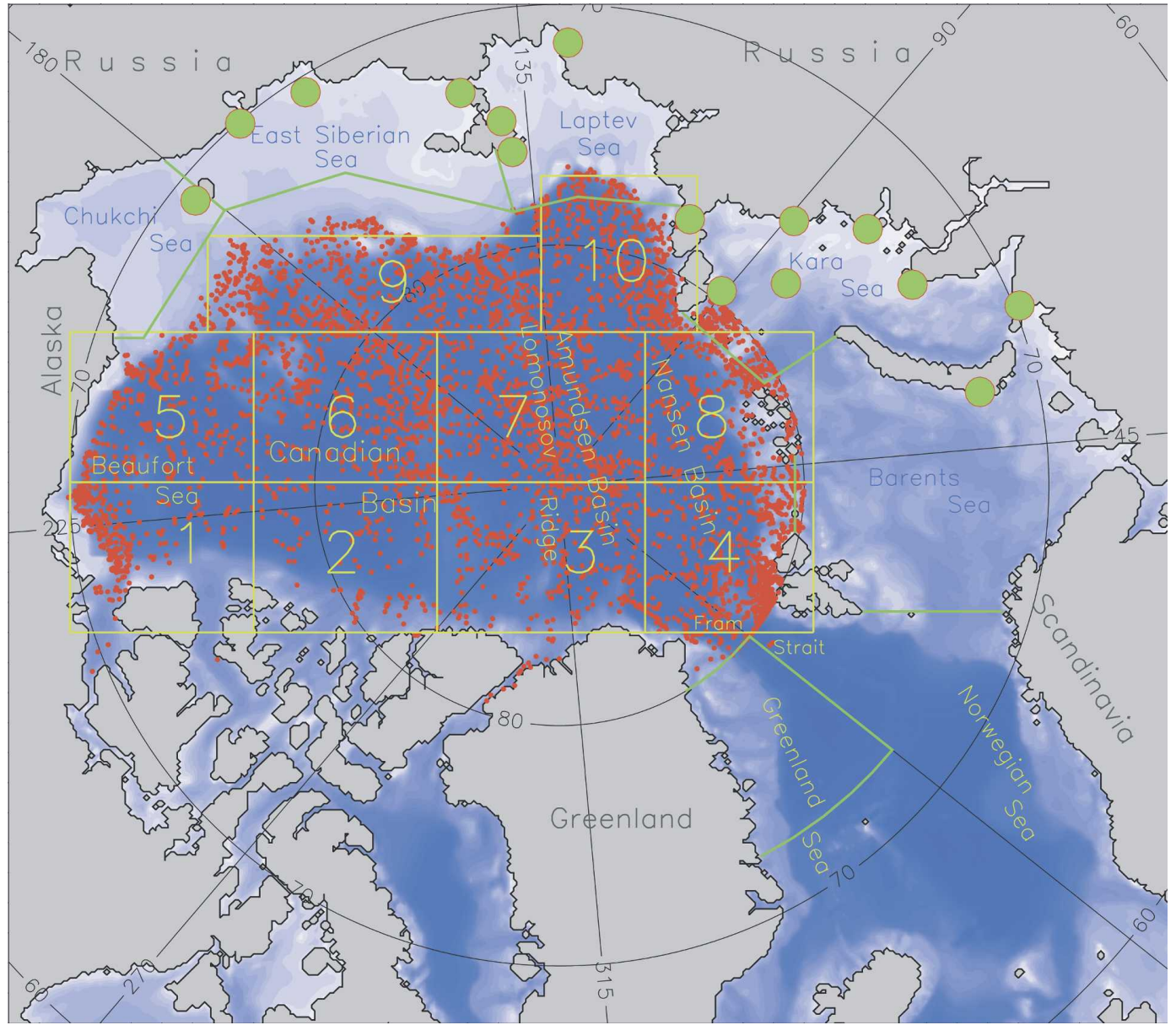

FIG. 1. Map of the Arctic Ocean. The locations of deep-basin oceanographic stations used in this study are shown by red dots. Shelf-area oceanographic stations are not shown to avoid making the figure too busy. Boxes delineate regions used in the analysis of the central ocean FWC. Green lines mark Siberian and Greenland-Barents Seas regions used for regional FWC estimates. Green dots denote stations where fastice-thickness data were collected.

the analysis of a vast collection of previously unsynthesized observational data, we examine freshwater changes in the Arctic Ocean and its marginal seas over the twentieth century. Using a combination of several datasets we identify major causes of these long-term changes and quantify their contributions. Particular attention is paid to recent decades when the Arctic and sub-Arctic regions have undergone substantial changes (Morison et al. 2000; Serreze et al. 2000; Houghton et al. 2001; Dickson et al. 2002; ACIA 2005; Overland et al. 2004; Curry and Mauritzen 2005; Polyakov et al. 2007). We make an attempt to identify the degree to which these changes reflect long-term trends or the low-frequency oscillation (LFO) with a time scale of $50-80 \mathrm{yr}$, which is evident in many instrumental and proxy records from the Northern Hemisphere in general (Delworth and Mann 2000; Polyakov et al. 2005) and the Arctic in particular (Mysak et al. 1990; Yi et al.
1999; Polyakov et al. 2003a,b, 2004; Venegas and Mysak 2000; Polyakov and Johnson 2000).

Following these objectives, the paper includes data and method descriptions (section 2 and appendix A) and analysis of long-term trends and variations of Arctic Ocean FWC (section 3) and suggests factors controlling the high-latitude FWC change (section 4). Major conclusions are given in section 5 .

\section{Data and methods}

The area of the Arctic Ocean including the Siberian marginal seas (Kara, Laptev, East Siberian, and Chukchi) is shown in Fig. 1. Important milestones for the beginning of the history of oceanographic observations on the Siberian shelf were expeditions aboard the Russian vessel A. Pervozvannii (Kara Sea, 1906), the Norwegian ship Mod (Chukchi and East Siberian seas, 


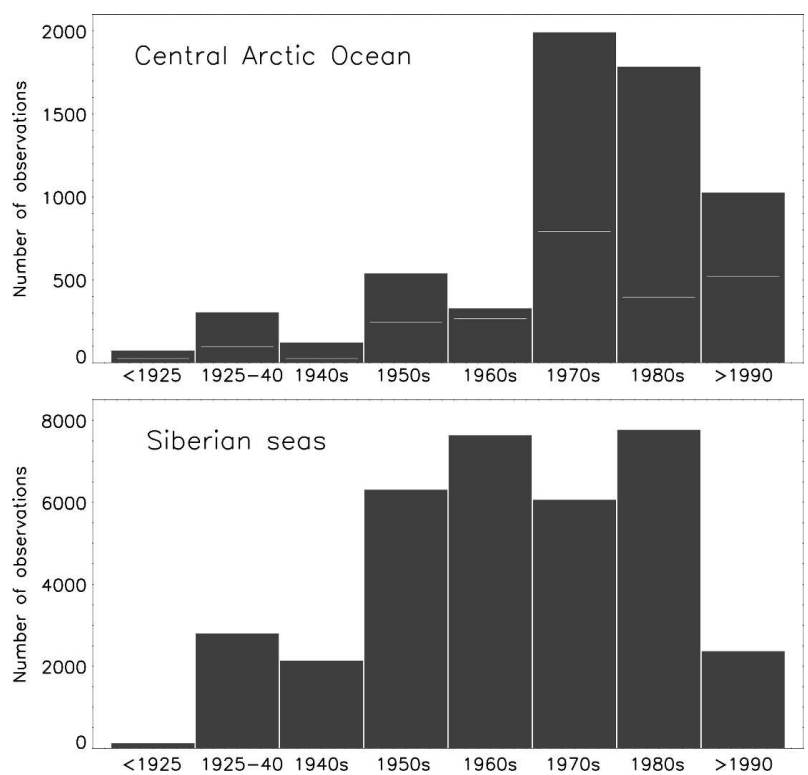

FIG. 2. Number of observational stations used for analysis of FWC. For comparison purposes, (top) white horizontal lines within the gray bars show the number of oceanographic stations used for analysis of the Atlantic Water core temperatures (Polyakov et al. 2004)

early 1920s), and the Russian icebreaker Sibiryakov (Laptev Sea, 1932). Episodic oceanographic observations in the Siberian seas persisted, but only after World War II (1939-45) did systematic observations begin, mostly in the summer period in ice-free areas. In the 1960s the observational program on the Siberian shelf was expanded for the winter period when Russians launched a program of winter aircraft surveys called "Sever" (North).

A detailed description of data sources for the central Arctic Ocean may be found in Polyakov et al. (2004). The observational database consists of updated datasets previously used for analysis of long-term variations of the Atlantic Water (AW) core temperature (AWCT). Since then, many new oceanographic stations were added to this database [see Figs. 1 and 2 in this paper and Fig. 1 from Polyakov et al. (2004) for comparison]. The most valuable addition came from several Russian North Pole manned drifting stations, which provided much-needed data for the central basin (see Gorshkov 1980 for station trajectories). Even though these additional data led to negligible changes in updated AWCT time series (not shown), they were extremely valuable for our analysis of FWC in the upper, most variable layer of the Arctic Ocean, particularly because salinity records are generally much noisier than temperature records.

Most historical (prior to the 1980s) observations used
Nansen bottles to obtain water samples and measure temperatures and salinities. Although they have rather coarse vertical resolution, these data provide reasonable horizontal coverage for the purposes of this research, and the multiyear coverage makes the data an invaluable resource for understanding interannual variations of the water-mass structure within the Arctic Ocean. The typical measurement errors are $0.01^{\circ} \mathrm{C}$ for temperature and 0.02 for titrated salinity. In recent years observations have been based on conductivitytemperature-depth (CTD) measurements, which have accuracies an order of magnitude greater than the bottle measurements.

For each central Arctic Ocean oceanographic profile, salinity was averaged over constant-thickness $(z)$ layers of $0-100,0-150,50-100$, and $100-150 \mathrm{~m}$ and also over variable-thickness layer limited by the sea surface and by a density surface of $\sigma_{\theta}=27.35$. On average, the depth of this surface is $140-150 \mathrm{~m}$, which is slightly above the AW upper boundary defined by the $0^{\circ} \mathrm{C}$ isotherm. Because of noise in the data (which is probably due to strong undersampled variability), estimates of salinity anomalies within the 0-50-m layer precluded meaningful conclusions (not shown). The vertically averaged water salinities were then reduced to their anomalies $\left(S^{\prime}\right)$ by subtracting local monthly means. FWC anomalies $\left(\mathrm{FWC}^{\prime}, \mathrm{m}\right)$ were calculated by dividing $S^{\prime}$ by local climatological means and multiplying by the local thickness of the upper layer similar to Curry and Mauritzen (2005). To our knowledge, Aagaard and Carmack (1989) were the first who suggested to use different reference salinities for FWC budgets for different high-latitude regions. Linear interpolation was used throughout this study to obtain FWC spatial distributions.

The FWC anomalies (FWC') were then used to compute composite time series (Fig. 3). We employed the so-called grid-averaging method that was used for the analysis of the long-term variability of the intermediate AWCT of the Arctic Ocean (Polyakov et al. 2004) and of the water temperature and salinity of the North Atlantic (Polyakov et al. 2005). In this method, the Arctic Ocean is divided into 10 boxes of approximately equal areas (Fig. 1), and individual (snapshot) FWC anomalies in these boxes are averaged within a given year and box to produce 10 regional time series $\left(\overline{\mathrm{FWC}}^{\prime}\right)$. The length of the regional composite records together with regional vertically averaged salinity means and standard deviations is shown in Table 1 . The resulting average regional time series of $\overline{\mathrm{FW}} \mathrm{C}^{\prime}$ for each grid box are averaged again, taking into account the areas of each box, to obtain a single "global" time series $\left(\mathrm{km}^{3}\right.$, Fig. 3). The same method was also used to generate 


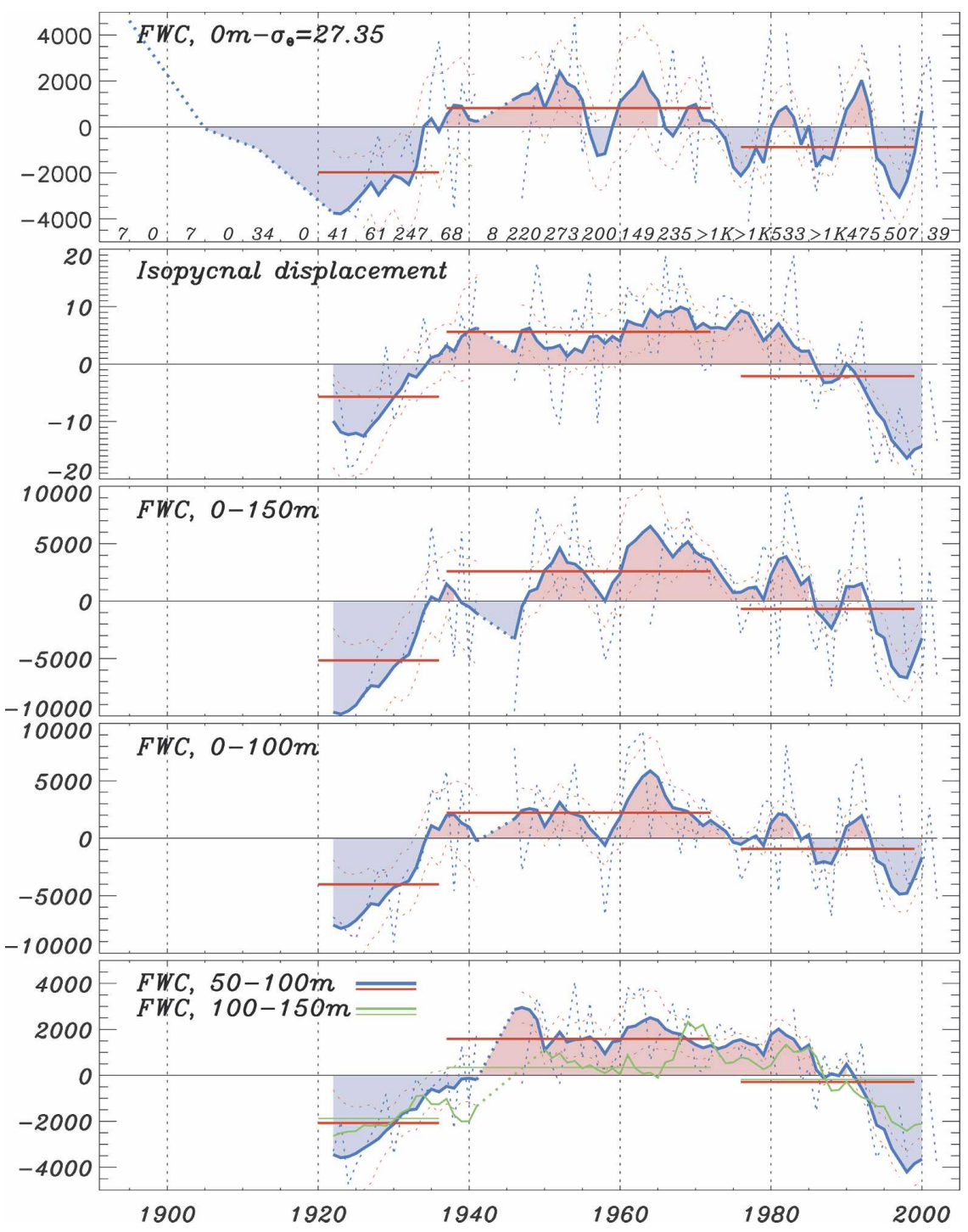

FIG. 3. The Arctic Ocean FWC $\left(\mathrm{km}^{3}\right)$ anomalies in the $\sigma_{\theta}$ layer and in the 0-150-, 0-100-, and 50-100-m $z$ layers. Changes of $\sigma_{\theta}$-layer thickness (or isopycnal displacement, meters) are also shown. Annual anomalies are shown by blue dotted lines, 6-yr running means are shown by blue thick lines (dotted segments represent gaps in the records), and red dotted lines show their $98 \%$ confidence intervals. Red horizontal lines show long-term mean anomalies. (top) Numbers at the bottom denote the 5-yr averaged number of stations used in the data analysis. (bottom) For comparison purposes 6-yr running mean FWC anomalies and long-term means for the 100-150-m $z$ layer are shown by green lines.

composite time series of salinity anomalies (not shown) and thickness of the upper-Arctic Ocean layer (reduced to anomalies by subtracting long-term mean, as is shown in Fig. 3). It is important to emphasize that our budget estimates are estimates of anomalies and not means.

For consistency, the grid-averaging method was also used to compute a composite FWC anomaly time series for the Siberian marginal seas (Fig. 4). There were, however, some important differences. First, we used the entire collection of available data (13978, 7839, 6101, and 7396 oceanographic stations from the Kara, Laptev, East Siberian, and Chukchi seas, respectively, totaling to almost 35000 stations) to build monthly and annual climatologies for each sea. For each month, available original data were interpolated on a grid with a uniform $50-\mathrm{km}$ horizontal resolution and a $1-\mathrm{m}$ vertical resolution covering the areas marked by the green line in Fig. 1. Next, for each original profile, salinity was integrated vertically over constant-depth $(z)$ layers of 
TABLE 1. Regional means $\left(\bar{S}_{\text {reg }}\right.$ and $\left.\bar{H}_{\text {reg }}\right)$ and standard deviations $\left(\sigma_{\text {reg }}^{S}\right.$ and $\sigma_{\text {reg }}^{H}$ ) for salinity $S$ and upper-layer thickness $H$ (m) and the length $N$ (number of years with data) used to calculate these statistics.

\begin{tabular}{|c|c|c|c|c|c|c|c|c|c|c|}
\hline Region & 1 & 2 & 3 & 4 & 5 & 6 & 7 & 8 & 9 & 10 \\
\hline $\mathrm{N}$ & 28 & 16 & 37 & 43 & 23 & 38 & 44 & 45 & 49 & 53 \\
\hline \multicolumn{11}{|c|}{$0 \mathrm{~m}-\sigma_{\theta}=27.35$ layer } \\
\hline $\bar{S}_{\text {reg }}$ & 32.12 & 32.23 & 32.29 & 33.48 & 31.92 & 32.05 & 32.57 & 33.44 & 32.19 & 32.81 \\
\hline$\sigma_{\text {reg }}^{S}$ & 0.23 & 0.22 & 0.26 & 0.44 & 0.23 & 0.15 & 0.46 & 0.44 & 0.31 & 0.41 \\
\hline $\bar{H}_{\text {reg }}$ & 186.3 & 179.2 & 138.9 & 77.7 & 191.0 & 173.5 & 121.4 & 65.6 & 132.0 & 91.5 \\
\hline$\sigma_{\text {reg }}^{H^{G}}$ & 8.8 & 11.3 & 18.8 & 18.6 & 16.9 & 23.7 & 17.1 & 14.2 & 20.5 & 11.6 \\
\hline \multicolumn{11}{|c|}{ 0-150-m layer } \\
\hline $\bar{S}_{\text {reg }}$ & 31.81 & 31.99 & 32.44 & 34.05 & 31.51 & 31.87 & 31.87 & 34.04 & 32.45 & 33.40 \\
\hline$\sigma_{\text {reg }}^{S}$ & 0.29 & 0.28 & 0.35 & 0.49 & 0.40 & 0.29 & 0.48 & 0.35 & 0.41 & 0.33 \\
\hline \multicolumn{11}{|c|}{ 0-10-m layer } \\
\hline $\bar{S}_{\mathrm{reg}}$ & 31.27 & 31.64 & 31.82 & 33.73 & 30.95 & 31.29 & 32.22 & 33.80 & 31.77 & 32.89 \\
\hline$\sigma_{\text {reg }}^{S}$ & 0.40 & 0.44 & 0.38 & 0.61 & 0.56 & 0.28 & 0.56 & 0.39 & 0.47 & 0.46 \\
\hline
\end{tabular}

0-30 and 0-50 $\mathrm{m}$ (or to the bottom if the local depth was smaller than the lowest $z$ level) and local FWC anomalies were obtained. Since most changes in the Arctic marginal seas occur well within the upper 3050-m layer (Steele and Ermold 2005), our choice of a 50-m depth limit as primary for our study is well justified. Local FWC anomalies were then interpolated into each grid cell with a $150-\mathrm{km}$ search radius and the resulting single basinwide time series for each sea was obtain by averaging the gridded time series (Fig. 4).
The composite time series for the entire Siberian shelf is obtained as a sum (weighted by the area of the sea) of the four time series (Fig. 4, top).

The analysis area for the Greenland Sea is limited by $72^{\circ} 30^{\prime}-80^{\circ} \mathrm{N}$ and $40^{\circ} \mathrm{W}-0^{\circ}$. This region is defined based on temperature and salinity climatic distributions where outflow of waters from the Arctic Ocean within the East Greenland Current is important. The number of stations used for this analysis is 7404. The data coverage is good considering the small area of the region,

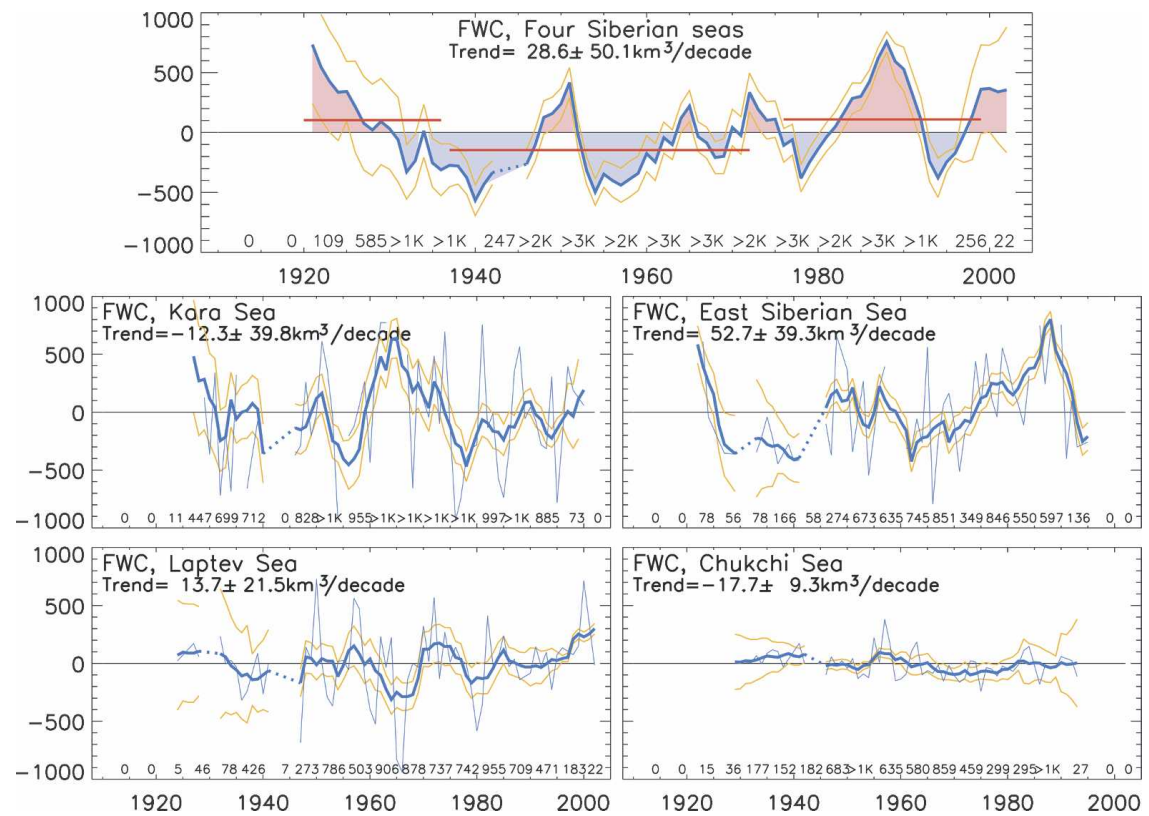

FIG. 4. Long-term variability of the FWC $\left(\mathrm{km}^{3}\right)$ of the upper 50-m layer of the Siberian marginal seas. Annual anomalies are shown by blue thin lines, 6-yr running means are shown by blue thick lines, and yellow lines show their $98 \%$ confidence intervals (dotted segments represent gaps in the records). (top) Red horizontal lines show long-term means. Numbers at the bottom of each panel denote the 5-yr averaged number of stations used in the data analysis. Trends are shown for 1920-2003. 
TABLE 2. FWC trends and long-term anomalies $\left(\mathrm{km}^{3}\right)$. Here $H=$ anomalous thickness of the $\sigma_{\theta}$ layer $(\mathrm{m})$, KS $=\mathrm{Kara}$ Sea, LS $=$ Laptev Sea, ES = East Siberian Sea, and CS = Chukchi Sea. A useful hint for interpretation of these anomalies: a freshwater anomaly of $2000 \mathrm{~km}^{3}$ spread over 5.72 million $\mathrm{km}^{2}$ of the central Arctic Ocean is equivalent to about $0.35 \mathrm{~m}$ of inventory, or about $10 \%-15 \%$ of the inventory present as pack ice.

\begin{tabular}{|c|c|c|c|c|c|}
\hline & \multicolumn{2}{|c|}{ Trend } & \multicolumn{3}{|c|}{ Long-term mean anomalies } \\
\hline & 1920-2003 & $1955-2003$ & $1920-36$ & $1937-72$ & $1975-2003$ \\
\hline \multicolumn{6}{|c|}{ Arctic Ocean } \\
\hline$H\left(0 \mathrm{~m}-\sigma_{\theta}\right)$ & $-0.4 \pm 0.6$ & $-5.0 \pm 0.8$ & $-5.7 \pm 0.1$ & $5.6 \pm 0.1$ & $-2.1 \pm 0.0$ \\
\hline $\mathrm{FWC}\left(0 \mathrm{~m}-\sigma_{\theta}\right)$ & $103 \pm 279$ & $-235 \pm 354$ & $-2066 \pm 37$ & $877 \pm 24$ & $-944 \pm 17$ \\
\hline $\mathrm{FWC}(0-150 \mathrm{~m})$ & $407 \pm 278$ & $-1970 \pm 356$ & $-5284 \pm 63$ & $2751 \pm 37$ & $-789 \pm 17$ \\
\hline $\operatorname{FWC}(0-100 \mathrm{~m})$ & $211 \pm 329$ & $-1314 \pm 418$ & $-4164 \pm 46$ & $2382 \pm 29$ & $-1044 \pm 21$ \\
\hline $\operatorname{FWC}(50-100 \mathrm{~m})$ & $-10 \pm 147$ & $-1276 \pm 190$ & $-2106 \pm 17$ & $1667 \pm 13$ & $-339 \pm 8$ \\
\hline $\mathrm{FWC}(100-150 \mathrm{~m})$ & $203 \pm 148$ & $-558 \pm 83$ & $-1870 \pm 15$ & $360 \pm 10$ & $-187 \pm 6$ \\
\hline \multicolumn{6}{|c|}{ Siberian seas, $0-50 \mathrm{~m}$} \\
\hline FWC, All & $29 \pm 50$ & $103 \pm 65$ & $103 \pm 20$ & $-147 \pm 4$ & $109 \pm 6$ \\
\hline FWC, KS & $-12 \pm 40$ & $-31 \pm 40$ & $76 \pm 27$ & $53 \pm 8$ & $-126 \pm 31$ \\
\hline FWC, LS & $14 \pm 22$ & $42 \pm 28$ & $40 \pm 42$ & $-58 \pm 8$ & $2 \pm 3$ \\
\hline FWC, ES & $53 \pm 39$ & $102 \pm 52$ & $-59 \pm 36$ & $-100 \pm 6$ & $272 \pm 4$ \\
\hline FWC, CS & $-18 \pm 9$ & $-21 \pm 12$ & $56 \pm 25$ & $2 \pm 1$ & $-22 \pm 25$ \\
\hline
\end{tabular}

however their density deteriorates toward Greenland. Analysis was based on the grid-averaging method with the grid steps of $0.25^{\circ}$ along latitudes and $0.5^{\circ}$ along longitudes. Seasonal signal was removed using monthly climatologies that were built using $150-\mathrm{km}$ search radius. Estimates of salinity/FWC anomalies for the upper $50 \mathrm{~m}$ of the Barents Sea are based on 74280 observations summarized in Matishov et al. 1998.

For analysis of long-term changes of ice volume and area we use various sources of observational data including upward-looking sonar (ULS), submarinebased, satellite, and Soviet ice landing observations blended with an advanced assimilation technique. This technique is based on estimates of Arctic ice age (Belchansky et al. 2005b) and drift (Fowler 2003) derived from satellite imagery. Sea ice thickness during 19822003 is estimated using neural network (NN) and reverse-chronology algorithms that assimilate in situ and quasi-observational data (Belchansky et al. 2004a, 2005a,b, 2006). Description of the assimilation technique is presented in appendix A. Robustness of our estimates is discussed in appendix B.

\section{Long-term trends and variations of Arctic Ocean freshwater content}

The time series of upper $\left(\sigma_{\theta}\right.$ layer) Arctic Ocean FWC anomalies (Fig. 3) displays a combination of decadal and multidecadal variability, with generally lower values (i.e., saltier ocean) in the 1910s-30s and in recent decades, and higher values (i.e., fresher ocean) in the 1950s-60s. Even though statistical significance of our estimates for particular years deteriorates in the earlier part of the record, a few available observations indicate that freshening dominated the FWC anomalies in the early twentieth century. The differences between longterm averages (horizontal red lines in Fig. 3, see also Table 2) emphasize different FWC conditions during prolonged fresher and saltier periods.

Time series of FWC anomalies for the upper 100- and 150-m $z$ layers are also shown in Fig. 3. Similarity between $z$ - and $\sigma_{\theta}$-layer records is evident. For example, a shift toward more saline conditions in the 1920s-30s and in recent decades is pronounced in all records. The latter salinification agrees with observational and modeling estimates (Steele and Boyd 1998; Häkkinen and Proshutinsky 2004; Swift et al. 2005; Steele and Ermold 2007). There are, however, some important differences between the $z$-and $\sigma_{\theta}$-layer estimates: while the latest transition from a fresher to a saltier state occurred in the $\sigma_{\theta}$ layer in the mid-1970s, the timing of this transition within the $z$ layers is shifted toward more recent decades. Moreover, $z$-layer FWC anomalies are substantially amplified (in some cases more than doubled) compared with $\sigma_{\theta}$-layer anomalies (Table 2 and Fig. 3). Occurrence of the AW core and upper boundary in the central Arctic Ocean in the 1990s at a shallower depth than during the 1970s is well documented (Carmack et al. 1997; Swift et al. 1997; Polyakov et al. 2004) and there should be no surprise at finding a strong contribution of isopycnal heaving caused by enhanced AW inflow in shaping FWC anomalies in the upper-ocean $z$ layers. Thus, limiting analysis by the $z$-layer approach we may obscure the real magnitude and causes of widespread persistent changes in the upper-ocean watermass structure. Our analysis, indeed, demonstrates that enhanced AW inflow working in unison with changes in 

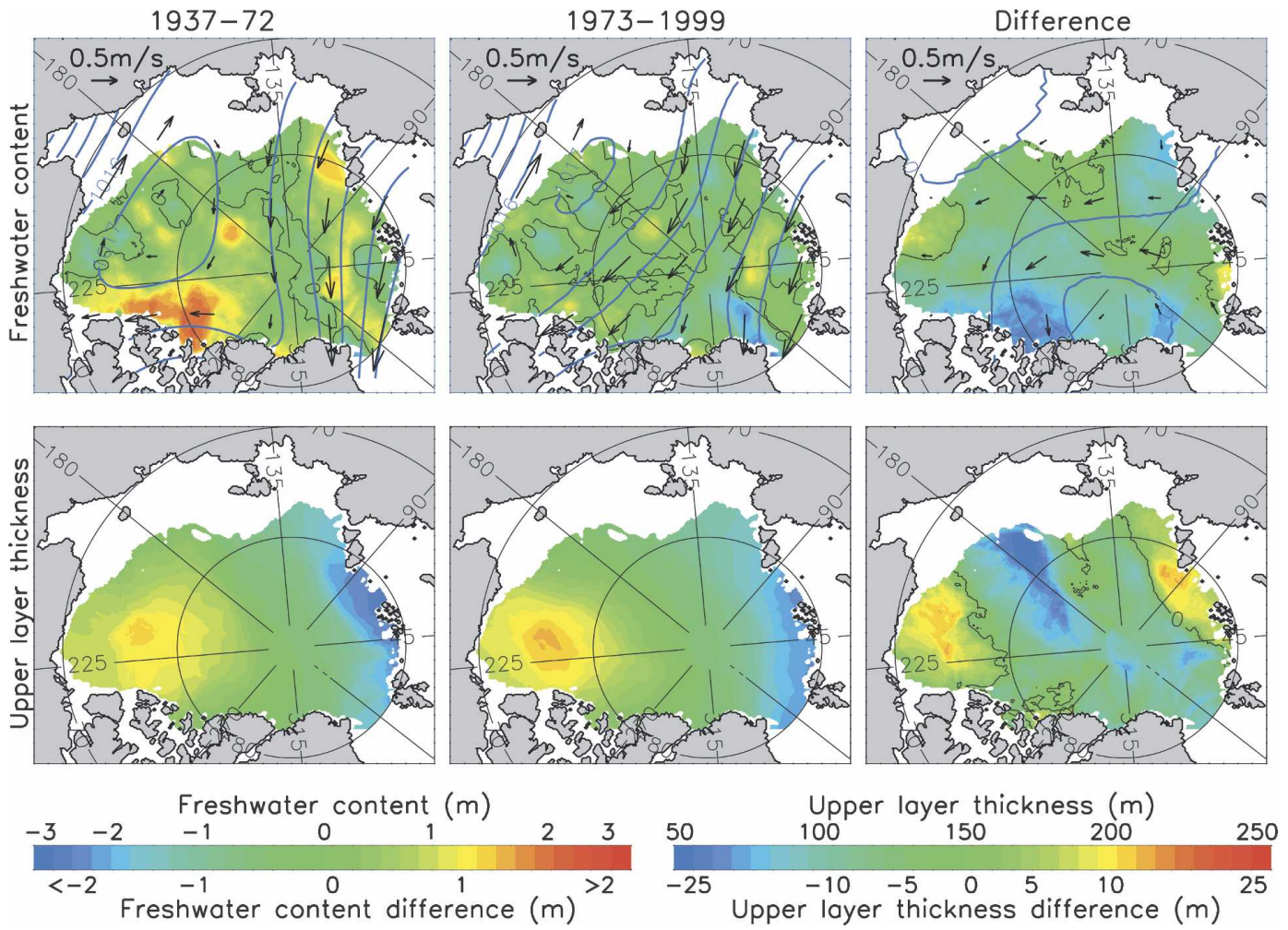

FIG. 5. Spatial distributions of the Arctic Ocean (top) FWC anomalies and (bottom) thickness of the upper layer defined by the $\sigma_{\theta}=27.35$ surface averaged over (left) negative and (center) positive phases of multidecadal variability, and (right) their difference. (left), (middle) Thick blue lines and arrows show sea level pressure and geostrophic wind averaged over the same periods, and (right) their difference.

the upper-Arctic Ocean layer exaggerates estimates of FWC anomaly magnitudes within the upper-ocean water masses.

The central Arctic Ocean century-long FWC trend (evaluated by the least squares technique) is $-239 \pm$ $270 \mathrm{~km}^{3}$ decade $^{-1}$ (i.e., over the twentieth century the Arctic Ocean became increasingly saltier). Change of the upper-layer thickness was very modest, only $0.1 \pm$ $0.6 \mathrm{~m} \mathrm{decade}^{-1}$. The $z$-layer-based FWC trends are substantially amplified compared with the $\sigma_{\theta}$-layer-based estimates (Table 2 and Fig. 3). Note however that these estimates (except the trend for the $0-150-\mathrm{m} z$ layer) have low statistical significance. Analyzing trends of various atmospheric, ice, and oceanic parameters, it was shown that the trends are strongly modulated by pronounced decadal and multidecadal variability, which may in some cases overwhelm long-term trends (Polyakov and Johnson 2000; Polyakov et al. 2003a,b, 2004). This conclusion may be extended to the FWC fluctuations showing oscillatory behavior of trends (Table 2). For example, during the previous $80 \mathrm{yr}$ (since the 1920s) anomalous FWC trends were positive. However, the upper Arctic Ocean was fresher in the 1950s- 60s and saltier in recent decades, so that from the 1950s onward the data show a tendency toward a saltier upper ocean. This analysis underscores the inherent difficulty in differentiating between trends and long-term fluctuations.

Maps of FWC anomalies for the $\sigma_{\theta}$ layer provide clear evidence of sustained and widespread salinification of the upper Arctic Ocean over the past several decades (Fig. 5). For example, in the 1950s-60s, associated with the negative phase of multidecadal variability, both composite time series and maps show strong freshening in the upper Arctic Ocean, probably due to enhanced outflow of fresh polar water through straits (Figs. 3 and 5). Decadal signal is also clearly seen in the spatial distributions and its magnitude is comparable to the magnitude of the longer time scale signal (Fig. 6). The thickness of the upper layer exhibited substantial changes over decadal and multidecadal time spans (Figs. 5 and 6). Similar saddle-like spatial patterns of the longer time scale AW elevation anomalies and upper-layer thickness anomalies [cf. Fig. 5 from Polyakov et al. (2004) with Fig. 5 from this study] suggest that some common mechanisms are involved in shaping 

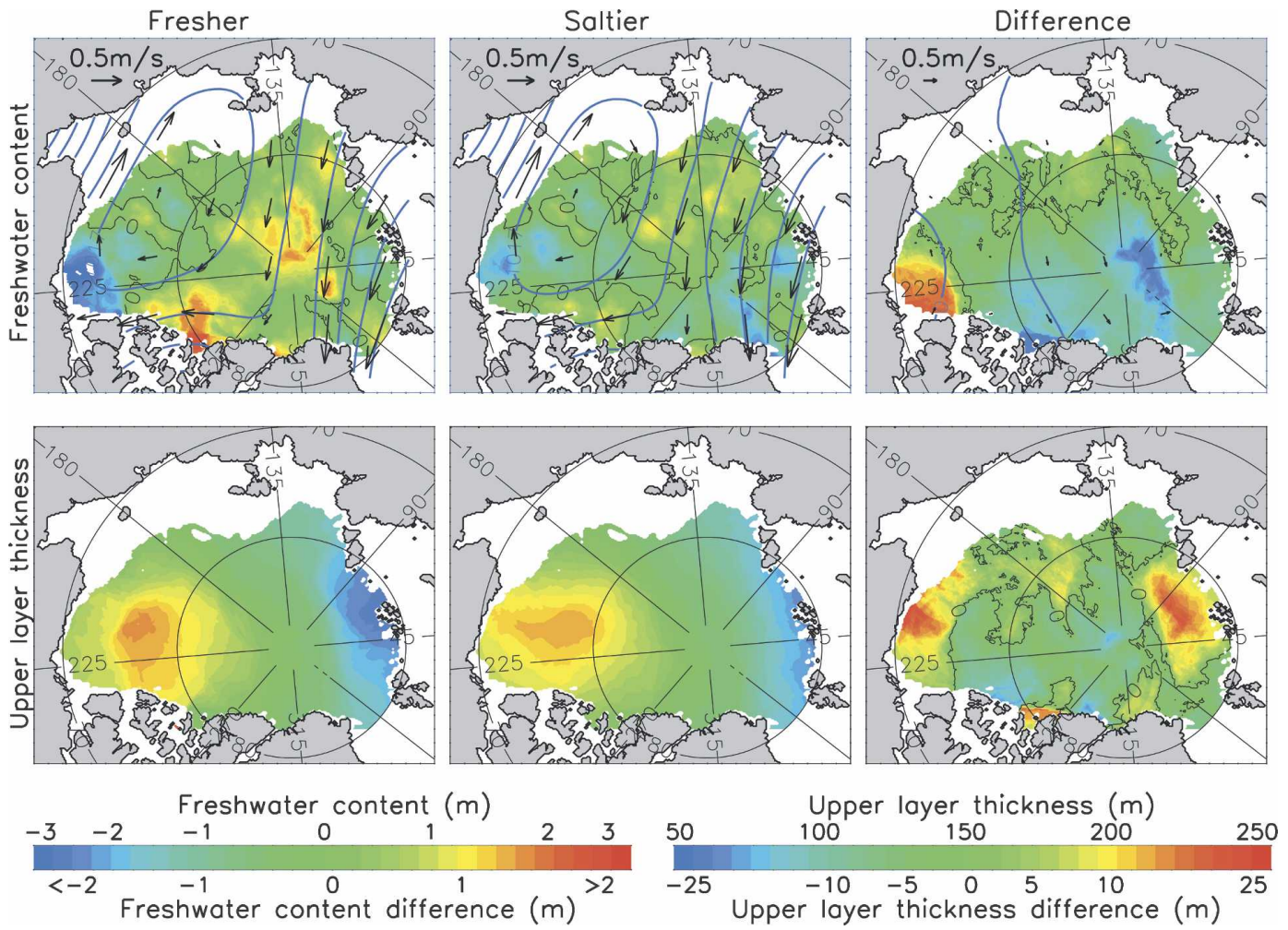

FIG. 6. Spatial distributions of the Arctic Ocean (top) FWC anomalies and (bottom) thickness of the upper layer defined by the $\sigma_{\theta}=27.35$ surface averaged over phases of the decadal mode with (left) increasing (1958-63, 1968-70, 1977-82) and (center) decreasing (1953-57, 1964-67, 1971-76) FWC, and (right) their difference. (left), (middle) Thick blue lines and arrows show sea level pressure and geostrophic wind averaged over the same periods, and (right) their difference.

both natural layers of the Arctic Ocean. Note that spatially averaged differences of upper-layer thickness anomalies nearly compensate for each other at the decadal time scale (cf. $143 \mathrm{~m}$ for the fresher phases and 144 $\mathrm{m}$ for the saltier phases) whereas at the multidecadal time scale the differences are larger (cf. $142 \mathrm{~m}$ for the fresher phase versus $137 \mathrm{~m}$ for the saltier phase, Figs. 5 and 6). This difference in the spatial decadal and multidecadal distributions may shed light on the reasons why the time series of the upper-layer thickness anomalies misses the decadal signal whereas it is well pronounced in the time series of FWC anomalies (Fig. 3).

A somewhat different angle on long-term FWC changes within the upper-Arctic Ocean water masses is given by volumetric $\theta-S$ plots ( $\theta$ is potential temperature, $S$ is salinity, Figs. 7 and 8 ) showing the volumes of water found in $\theta-S$ bins $0.33^{\circ} \mathrm{C} \times 0.5$ in size. Giving multiyear bin-average values, the histograms illustrate gain or loss of water by the main water-mass constituents where the dominant water masses are the halocline waters of different origins, characterized by $-1.5^{\circ} \mathrm{C}<\theta$ $<0^{\circ} \mathrm{C}$ and $S>33$, and the cold surface waters with temperatures near the freezing point $\left(\theta<-1.5^{\circ} \mathrm{C}\right)$. Our water-mass census shows substantial long-term variations. For example, with volumetric single-bin fluctuations of up to $30-40 \mathrm{~km}^{3}$ the halocline and surface waters form a bipolar pattern of multiyear anomaly fluctuations with water losses by the halocline and gains by relatively warm and fresh waters in recent decades (Fig. $7 \mathrm{c})$. Decadal anomaly fluctuations also show substantial reduction in the volume of halocline waters (but to a lesser degree compared with the longer-scale variations); however, dominating blue peaks at the lowest temperature bins indicate that the volume of surface waters was increased (Fig. 8c). Note that all the above estimates are statistically significant at the $98 \%$ level.

\section{Factors controlling the upper-Arctic Ocean freshwater content}

\section{a. Shelf-central basin interactions}

In this section, potential sources for the observed long-term changes found in the central Arctic Ocean FWC will be sought and we begin with the role of river discharge and Arctic shelves. Over the last $80 \mathrm{yr}$ the Siberian shelf FWC has shown substantial changes with 


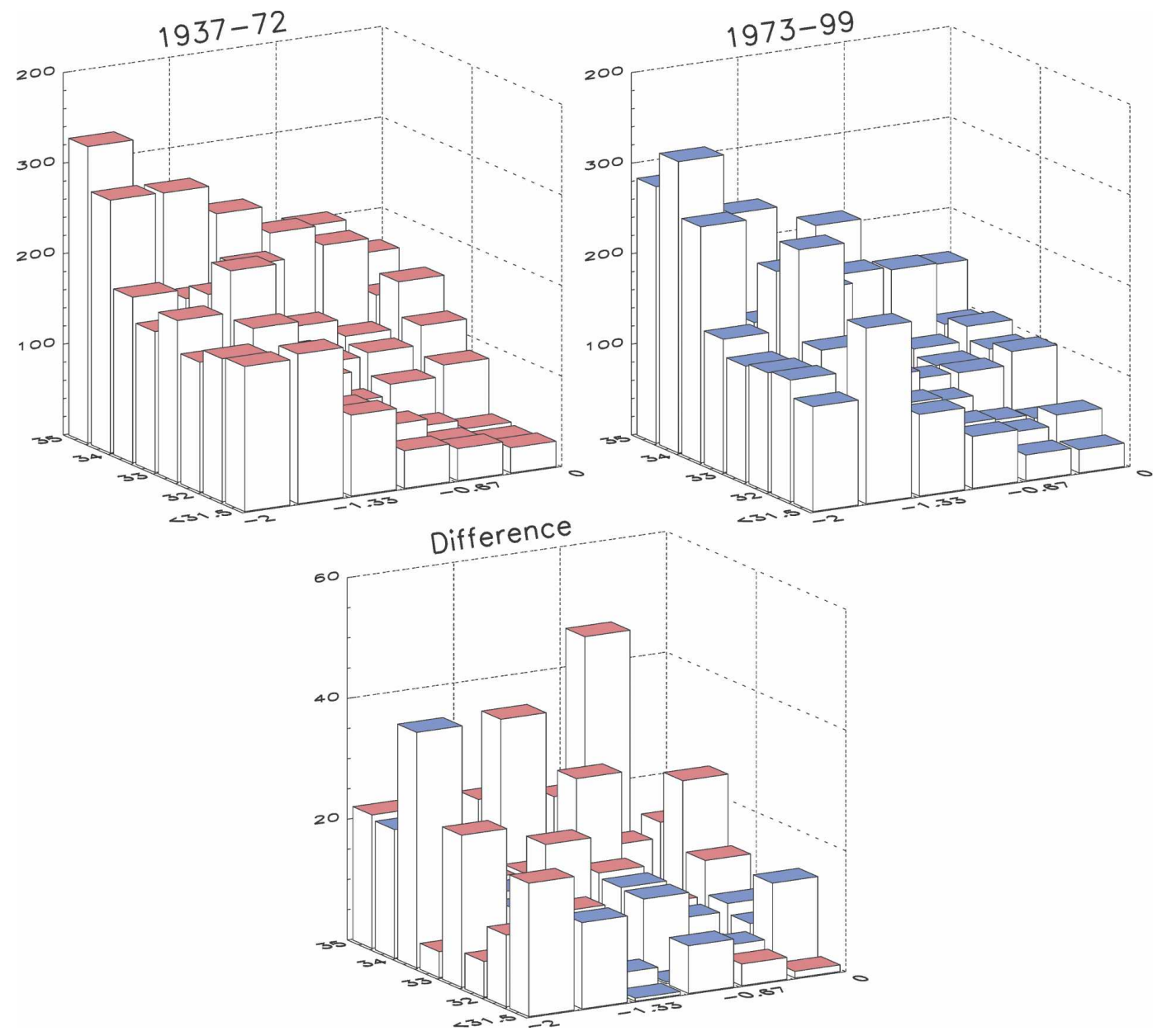

FIG. 7. Volumetric $\theta-S$ diagram showing volumes $\left(\mathrm{km}^{3}\right)$ of water found in $\theta-S$ bins $0.33^{\circ} \mathrm{C} \times 0.5$ in size for (left) fresher and (right) saltier phases of multidecadal variability, and (bottom) their difference.

generally fresher waters in the 1930 s and recent decades and saltier waters in the 1940s-60s (Figs. 4 and 9). The overall freshening tendency agrees with the previous estimates made by Steele and Ermold (2005). Regional FWC anomalies demonstrate substantial departures from this general pattern with a particularly striking lack of variation on the Chukchi Sea shelf (Fig. 4), which is well supported by a lack of consistent trend in the observed water flux through the Bering Strait in 1990-2004 (Woodgate et al. 2005). The East Siberian Sea was the largest contributor to the freshening in recent decades and salinification in the mid-twentieth century, whereas freshening in the 1920s-30s was mostly dominated by contributions from the Kara Sea (Table 2). Long-term FWC trends provide additional evidence for the dominating freshening tendency on the Siberian shelf, with an accelerated rate of freshwater accumulation beginning in the 1940s-50s; in consequence, since the late-1950s the Siberian shelves have accumulated $10197 \pm 6435 \mathrm{~km}^{3}$ of freshwater (Fig. 4 and Table 2). Increased input of river discharge that started in the mid-1960s led to an important cumulative contribution to the observed freshening over the Siberian shelves of near $2800 \mathrm{~km}^{3}$ of freshwater over the last 35 yr (Fig. 9; cumulative values are estimated using linear trends). For the Siberian shelf FWC the 1960s marked the turning point from sustained negative (saltier) anomalies to positive (fresher) anomalies (Fig. 9); however the magnitude of the shift between the 1960s and the 1990s-early 2000s did not exceed several hundred cubic kilometers (Fig. 4), presumably due to the moderating effect of exchanges with the Arctic Ocean interior that was becoming increasingly salty, and to ice formation processes. According to Peterson et al. (2006), the magnitude of freshwater inputs from melting glaciers was small and could not have made an important contribution to the FWC changes over the Arctic shelves. 


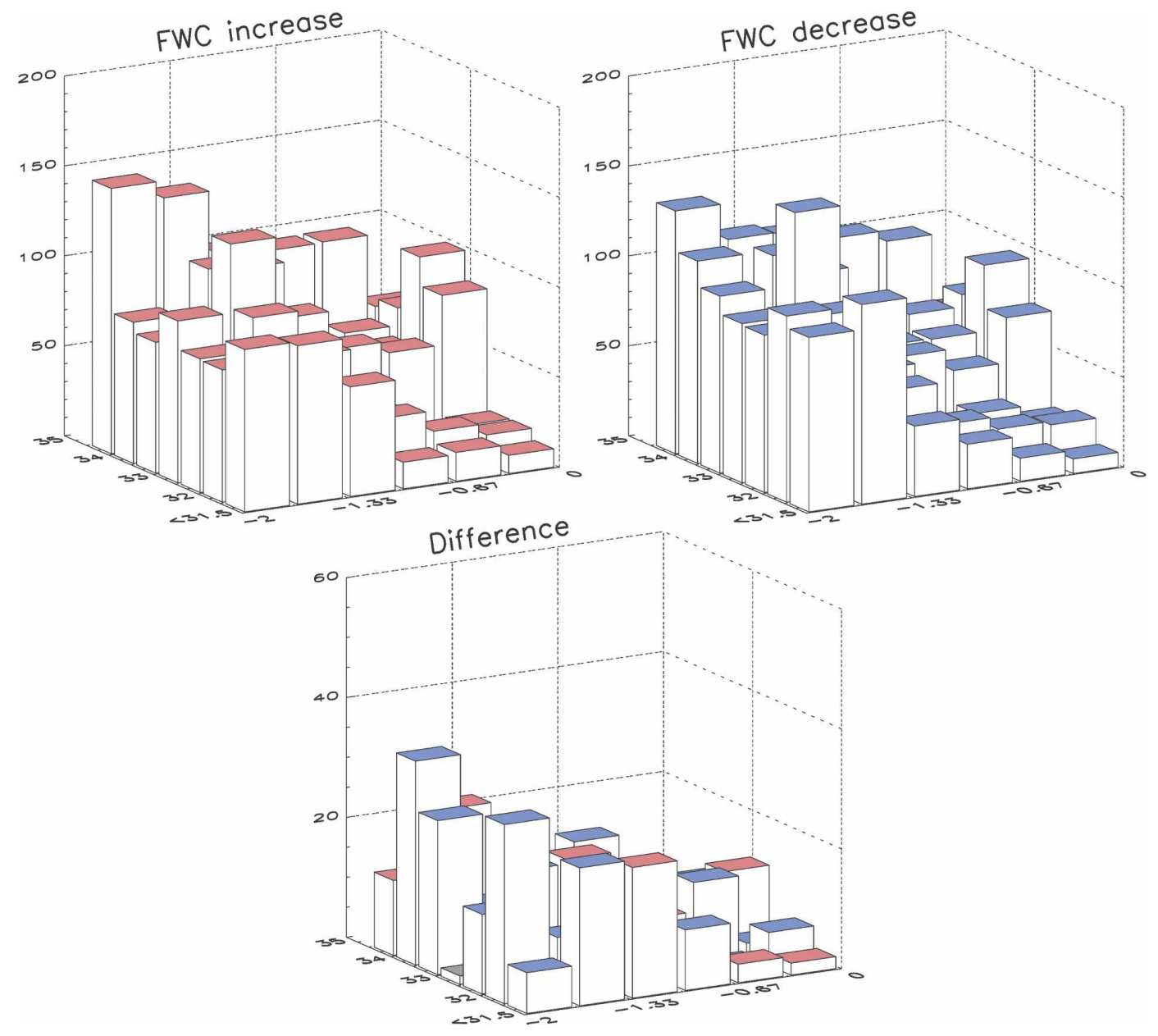

FIG. 8. Volumetric $\theta-S$ diagram showing volumes $\left(\mathrm{km}^{3}\right)$ of water found in $\theta-S$ bins $0.33^{\circ} \mathrm{C} \times 0.5$ in size for the (left) fresher and (right) saltier phases of the decadal variability, and (bottom) their difference.

The exchanges between Arctic shelves and central basin are highly variable and are subject to a regulatory mechanism driven by alternating anticyclonic and cyclonic atmospheric circulation regimes (Steele and Boyd 1998; Johnson and Polyakov 2001). For example, observational data and results of coupled ice-ocean models suggest that the shift of atmospheric circulation patterns to more cyclonic in recent decades has resulted in an eastward diversion of Russian rivers (Steele and Boyd 1998; Dickson 1999; Johnson and Polyakov 2001; Maslowski et al. 2001). It is evident that there was a shift of wind pattern over the periods of saltier/fresher Arctic shelves: winds in 1973-99 had an alongcoast component, while in 1937-72 the prevailing winds were toward the central Eurasian Basin (Fig. 5). Changes in sea level pressure (SLP)-wind pattern are not as obvious when we consider the decadal mode of variability (Fig. 6); however, the SLP-wind patterns for the periods associated not with the decadal peaks (like in Fig. 6) but with slopes of FWC decadal anomalies (as suggested by J. Walsh, not shown) become surprisingly similar to the longer-scale patterns (Fig. 5). Thus, projecting results of the earlier studies onto the observed SLP/FWC anomaly patterns, we conclude that the atmospheric circulation regimes drove substantial changes in the Arctic Ocean hydrography.

One of the most striking features of FWC anomalies for the central basin and its shelves is that central-basin anomalies exceed those on the shelf by one order of magnitude (Fig. 9, see also Figs. 3 and 4 and Table 2). In addition, Fig. 9 suggests an out-of-phase variability in the central basin and on the shelves, where sustained phases of central Arctic Ocean freshening are associated with salinification of the shelf waters and vice versa. The opposition of long-term tendencies expressed by trends showing general salinification of the central basin and freshening of shelves complement this observation (Table 2, Figs. 3 and 4). Analysis of sea 

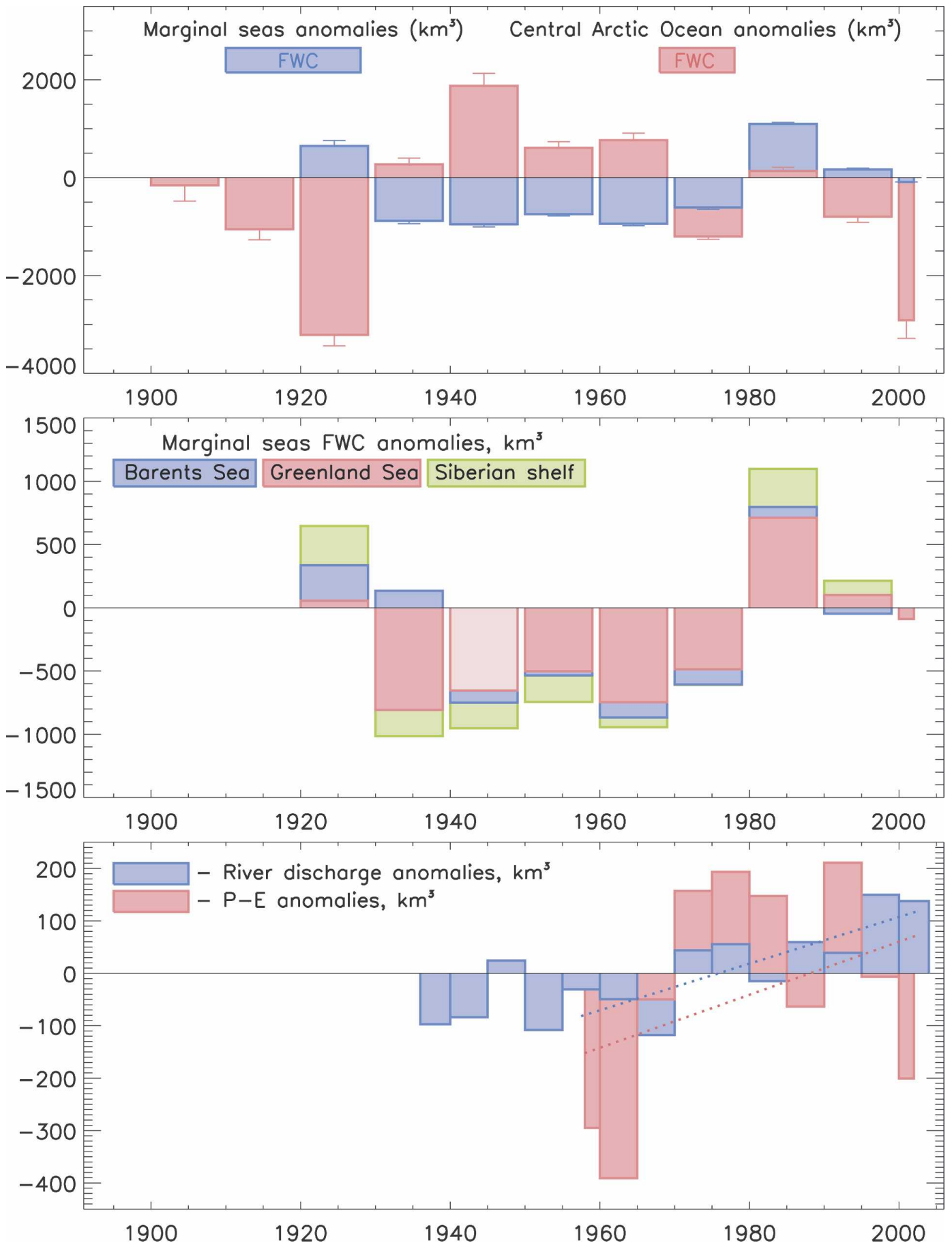

FIG. 9. (top) Decadal (except for the last two years) FWC anomalies $\left(\mathrm{km}^{3}\right)$ and their standard errors for the central Arctic Ocean and Greenland and Barents Seas. (middle) Decadal FWC for the Siberian marginal, Barents, and Greenland Seas. (bottom) Pentadal freshwater input anomalies of the $P-E$ over the Arctic Ocean (blue) and river discharge (adopted from Peterson et al. 2006). Linear trends over 1955-2002 are shown by dotted lines. Positive anomalies represent fresher basin or input leading to freshening. 
level changes also suggested out-of-phase variations over the Arctic shelves and deep basin (Proshutinsky et al. 2004). We conclude that the FWC anomalies generated on Arctic shelves (including river discharge inputs) cannot trigger the observed long-term FWC variations in the central Arctic Ocean; to the contrary, they tend to moderate long-term central-basin FWC changes.

\section{b. Vertical exchanges: Inputs from net precipitation and $A W$}

Now we discuss potential causes for the central Arctic Ocean FWC changes and we start with the impact of long-term variations of the net precipitation (precipitation minus evaporation, $P-E$ ) over the Arctic Ocean. Time series of annual $P-E$ anomalies is derived from the 40-yr European Centre for Medium-Range Weather Forecasts (ECMWF) Re-Analysis (ERA-40) dataset and kindly provided by J. Walsh (for further details, see Peterson et al. 2006). Similar to the river discharge, the $P-E$ input was increased from the mid1960 s leading to a cumulative freshwater contribution of $\sim 3150 \mathrm{~km}^{3}$ over the last $35 \mathrm{yr}$ (Fig. 9). The $P-E$ input varies in opposition to changes of the upperArctic Ocean FWC, the magnitude of the $P-E$ anomalies is measured by hundreds of cubic kilometers (not by thousands of cubic kilometers like the central Arctic Ocean FWC anomalies); their cumulative effect is rather modest (not shown), and cannot explain the observed salinification of the central basin over recent decades.

What impact might changes of the AW inflow have on the upper-Arctic Ocean FWC anomalies? In addition to the FWC variations in different layers of the upper Arctic Ocean, Fig. 3 illustrates the FWC changes due to intrusion of the AW from below. As evidenced from comparison of the observed changes in the 0-100and 100-150-m $z$ layers, the long-sustained freshening/ salinification of the upper ocean was not induced by the AW since the lower-layer changes were much weaker compared with the changes in the upper 100-m layer of the Arctic Ocean. To further illustrate this conclusion we constructed two additional composite time series of FWC anomalies for the 50-100- and 100-150-m layers (Fig. 3e). These time series provide additional evidence that changes in the upper layer were noticeably greater than changes in the lower layer (Fig. 3, see also Table 2 ). Thus, our analysis does not support the model-based hypothesis proposed by Zhang et al. (1998) and Häkkinen and Proshutinsky (2004) that the AW inflow may explain freshwater variations in the central basin. Note that elevation of the AW upper boundary in recent decades may result in a stronger impact of the AW on the upper-ocean water-mass structure via vertical mix- ing; however, based on available observational data we cannot quantify freshwater fluxes related to entrainment of the AW waters in the upper layer.

\section{c. Role of ice-cover fluctuations}

Now let us consider impacts that ice-volume variations have on changes in the upper-Arctic Ocean freshwater storage. Figure 10 shows estimates of ice-volume anomalies for 1982-2002 over the central basin and its Siberian shelf based on the NN assimilation technique (see appendix A for details of the NN method). Annual ice-thickness variations simulated by several models show surprisingly similar variations (see Fig. 12 from Rothrock et al. 2003). Similar to the oceanic FWC changes, ice-volume variations in the Arctic Ocean interior were much larger than those over the central basin's margins, exceeding for some years $1000 \mathrm{~km}^{3}$. During the 1980s some ice thickening (and associated salinification of the upper ocean, Fig. 10) resulted from persistent high-pressure conditions, colder surface air temperatures (SATs; Comiso 2003) and a stronger Beaufort Gyre (Rigor et al. 2002). In the late 1980s, when the atmospheric circulation shifted to a cyclonic phase, sea ice volume began decreasing (making the upper ocean fresher) because of longer melt seasons (Smith 1998; Belchansky et al. 2004b) and accelerated export of the oldest ice from the Arctic (Rigor and Wallace 2004; Belchansky et al. 2005b). Since the mid1990s, despite a persistence of long melt seasons (Belchansky et al. 2008) and record minimum extents (Serreze et al. 2003; Stroeve et al. 2005), the slight gain of sea ice volume in the central Arctic points out that extreme ice retreats do not imply ubiquitous thinning. Note that estimates of the ice-volume change rates based on the NN assimilation technique may have some bias due to lack of observational data in the area of heaviest, thickest ice adjacent to the Canadian Archipelago and northern Greenland coasts and due to a possible lack of ridged ice, which contribution was included via assimilation of submarine ice-thickness data and divergence/convergence index in forcing only. There is conflicting evidence regarding what component of the ice-thickness distribution (deformed or undeformed) contributed most to the observed loss in ice volume (e.g., Yu et al. 2004; Rothrock and Zhang 2005).

We still did not find a plausible explanation for the observed salinification in the central upper Arctic Ocean over recent decades; however, the modeling study by Johnson and Polyakov (2001) may provide a useful hint. The shift of atmospheric circulation pattern discussed in section $4 \mathrm{a}$ in relation to observed FWC 


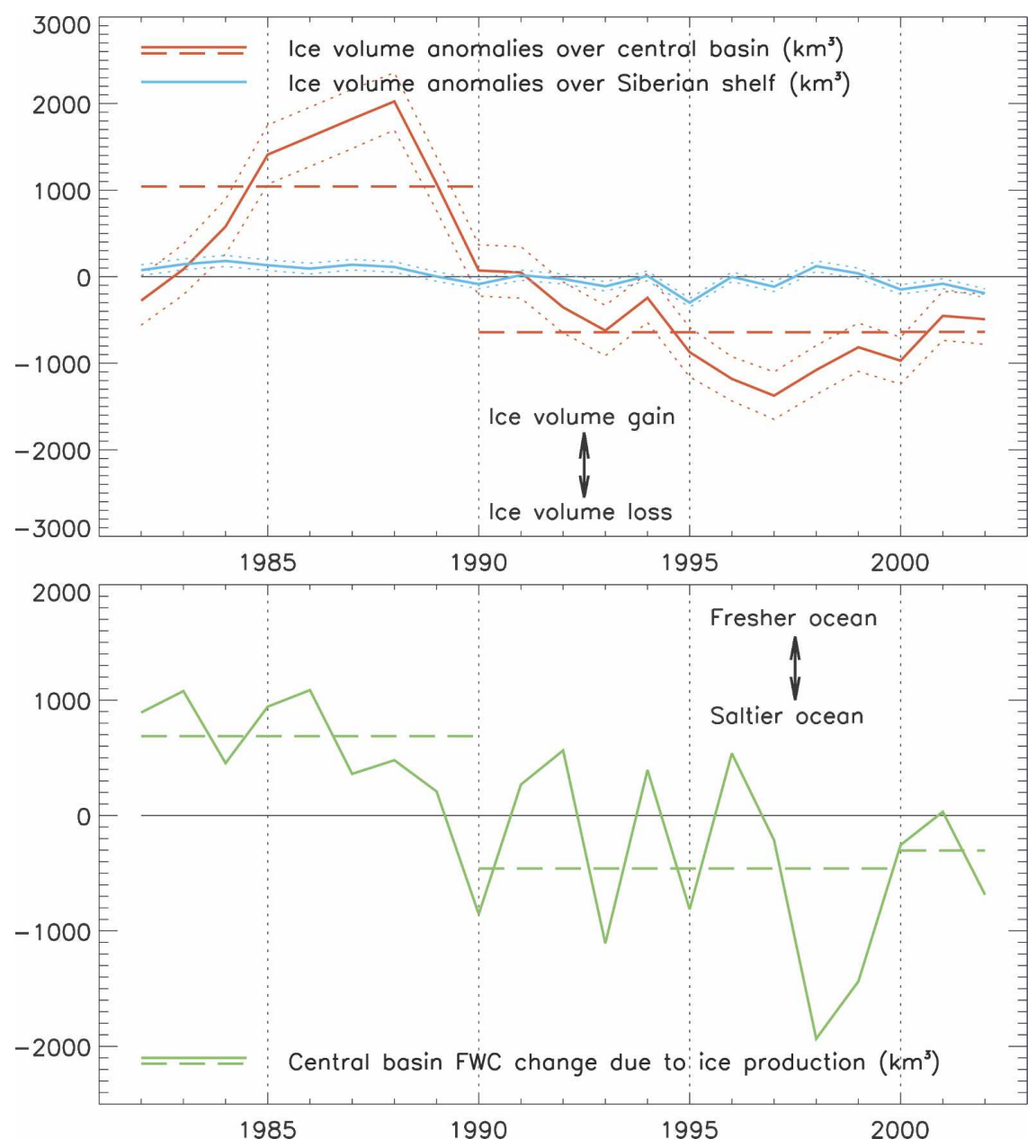

FIG. 10. (top) Ice-volume anomalies in the central Arctic Ocean and on the Siberian shelves. Dotted lines show 3 standard error uncertainties. (bottom) FWC anomalies due to ice production. Horizontal dashed lines show long-term means.

anomalies over the Arctic shelves had one more important implication: increased Arctic atmospheric cyclonicity in recent decades, which produced a record minimum in ice extent (Belchansky et al. 2005a; Stroeve et al. 2005). Analysis of results of numerical experiments revealed that increased brine formation due to enhanced ice production in numerous leads in the ice cover was essential to forming the positive salinity anomalies in the Eurasian Basin (Johnson and Polyakov 2001). According to these experiments, the strong salinization over the Eurasian Basin altered the formation of cold halocline waters. Swift et al. (2005) in an analysis of observational data also found that the central part of the Eurasian Basin was saltier in recent decades, and related this to enhanced ice production and salinization. They argued, however, that the salinization in the 1990s originated in the Eurasian Basin interior, not on the Laptev Sea shelf as the modeling results by Johnson and Polyakov (2001) suggested. Our analysis of regional anomalies shows that the salinization observed in the 1990s originated in region 10 covering the eastern, not central, part of the Eurasian Basin in close proximity to the Laptev Sea (Fig. 1), but not in the Laptev Sea proper (Fig. 4). Later this anomaly progressed to region 7, and in the late 1990s the weakened signal was found in region 3 supporting in general the scheme of anomaly propagation suggested by the model. Regardless of the exact location of the maximum ice production, this mechanism should be considered among the major contributors to the observed FWC changes in the upper Arctic Ocean.

To further examine and quantify the contribution of ice production to variability of the upper-central-ocean FWC, we estimated the rates of ice production due to changes both in atmospheric thermodynamical forcing and in ice area. The net heat flux was calculated using 
bulk formulas similar to those used in numerical Arctic Ocean models. Averaged over the area of the central Arctic Ocean, this flux was then used to calculate equivalent ice thickness. Multiplied by ice-free area it produced an estimate of annual ice production $\left(\mathrm{km}^{3}\right)$ and upper-ocean salinification (Fig. 10). The bulk of estimated salinification was due to an increase of icefree area, but not to direct atmospheric forcing. The salinification occurred with a rate of $-91 \pm 47 \mathrm{~km}^{3}$ $\mathrm{yr}^{-1}$, which is a much higher rate of change compared with any other previously discussed freshwater inputs suggesting that the ice production may be among major driving forces for the observed changes of the upperArctic Ocean water masses (however, more research is necessary to quantify competing inputs from ice melt and export of ice through straits). These estimates are well supported by substantial rejuvenation of Arctic ice observed over recent decades (Rigor and Wallace 2004; Belchansky et al. 2005b). Modeling results of Polyakov and Johnson (2000) also suggested that increased atmospheric cyclonicity in the 1990s favored lighter ice conditions in the Eurasian Basin when cyclonic winds flush multiyear ice from this area, and about $40 \%$ of multiyear thick ice to the north of the Laptev Sea has been replaced by thinner ice, in qualitative corroboration with observations. Lindsay and Zhang (2005) using modeling results also argued that since 1989 change of atmospheric circulation caused flushing of old ice out of the basin and an increase in the summer open water extent. The satellite-based records are short relative to the composite time series of the Arctic FWC anomalies (Figs. 3 and 4); however we speculate that ice-ocean interactions (as suggested by the above modeling results) have always been of major importance for FWC changes in the upper Arctic Ocean.

\section{d. Role of exchanges with neighboring basins}

Direct long-term observations of ice and water exchange between the Arctic Ocean and the North Atlantic are nonexistent. Therefore, in this study we use the FWC anomalies of the Barents and western Greenland Seas as indicators of these exchanges. Figure 9 shows that in general, sustained phases of freshening in the central Arctic Ocean are associated with salinification in these two seas (with much stronger anomalies in the Greenland Sea) and vice versa similar to out-ofphase Siberian shelf-central basin FWC variations. A few exceptions are the 1970s and 2000-02 when the anomalies were of the same sign. This seems paradoxical since much of the upper-Greenland Sea variability is advected from upstream locations in the Arctic Ocean by the East Greenland Current (EGC) through Fram Strait (Swift 1986; Aagaard et al. 1991; Woodgate et al. 1999), and it might be expected that a saltier/ fresher Arctic Ocean should therefore result in a saltier/fresher Greenland Sea. However, observations tell a very different story, and balance estimates may shed some light on this problem. Over time span $T$, the volumetric transport Fl of Arctic waters with salinity $S^{\text {ao }}=33.26$ through Fram Strait that would be required to change the salinity of the upper Greenland Sea $\left(S^{\mathrm{gr}}=34.71\right)$ with volume $\mathrm{Vol}^{\mathrm{gr}}$ by $d S^{\mathrm{gr}}$ is

$$
\mathrm{Fl}=\frac{d S^{\mathrm{gr}} \mathrm{Vol}^{\mathrm{gr}}}{\left(S^{\mathrm{ao}}-S^{\mathrm{gr}}\right) T}
$$

This simple formula shows that enhancement of outflow Fl from the Arctic Ocean by less than $0.02 \mathrm{~Sv}$ $\left(\mathrm{Sv}=10^{6} \mathrm{~m}^{3} \mathrm{~s}^{-1}\right)$ would explain the observed salinity decrease of $d S^{\mathrm{gr}}=0.2$ in the upper $150 \mathrm{~m}$ of the Greenland Sea between the two decades centered on 1965 and 1995. This is a moderate change for the EGC, which is famous for its rather high speed [e.g., Muench et al. (1992) estimated an average speed of $8 \mathrm{~cm} \mathrm{~s}^{-1}$ in the upper 35-150 $\mathrm{m}$ of the EGC; our suggested change of flow is within $1 \%$ of this value]. It would require altering this anomalous outflow by only $20 \%$ to offset the observed recent salinification of the Arctic Ocean. This estimate does not imply that impacts of highlatitude FWC changes are of minor importance for the sub-Arctic hydrological regime and Fig. 9 provides clear evidence that since 1980 the Greenland and Barents Seas, while remaining fresher than normal, became increasingly salty at approximately the same rate as did the Arctic Ocean. However, it strongly suggests that intensity of ice-water exchanges through straits connecting the Arctic Ocean with subpolar basins is of primary importance for the supply of Arctic freshwater to subpolar basins. We conclude that changes in largescale atmospheric and oceanic circulation may have a more profound effect on the freshwater flux to subpolar basins than variations of the Arctic Ocean FWC. Note also a possibility for enhanced transport of high-latitude freshwater to pass the Greenland and Iceland Seas without mixing with surrounding waters as suggested by Rudels et al. (2005) based on 2002 winter observations.

What impact does the link between the Arctic Ocean and the North Atlantic have on FWC changes in the Arctic Ocean? Steele and Ermold (2007) suggested that the observed salinification in the 1970 s was caused by sustained draining of freshwater from the Arctic Ocean in response to winds, and this loss of freshwater was probably balanced by enhanced salty AW inflow. Modeling results of Polyakov and Johnson (2000) showed that increased atmospheric cyclonicity in the 1940s 
through early 1950s and in the late 1980s-1990s favored an additional export of Arctic ice and freshwater into the Greenland and Barents Seas. The timing of simulated enhanced ice and freshwater export resembles major features of FWC changes (Fig. 3), attesting to a close connection between freshening/salinification in the central Arctic Ocean and ice and water outflows. However, further research is required to provide quantitative estimates of impacts freshwater fluxes may have on high-latitude FWC changes. There are also indications that the Canadian Archipelago may be another important conduit for the Arctic freshwater to the North Atlantic subpolar basin (Reverdin et al. 1997) but we do not have sufficient data to refine this conclusion.

\section{Conclusions}

We examined long-term variability in the freshwater content of the Arctic Ocean and its shelves using highlatitude hydrographic measurements going back to the late nineteenth-early twentieth century. This Arctic Ocean dataset was complemented by observational data from the Greenland and Barents Seas as well as by estimates of spatiotemporal distributions of ice volume based on an advanced assimilation technique using data from decades of satellite observations. Inputs of river discharge and $P-E$ were also used for our analyses. Despite gaps in the early part of the oceanographic records and shorter time series available for ice, atmospheric, and terrestrial parameters, the combination of these observational records proved to be invaluable in analysis of long-term variations of the Arctic Ocean FWC and factors controlling these variations. We summarize our primary conclusions as follows:

- Over the twentieth century the central Arctic Ocean became increasingly saltier with a rate of $239 \pm 270$ $\mathrm{km}^{3}$ decade $^{-1}$; long-term (1920-2003) FWC trends over the Siberian shelf provide evidence for a generally opposite tendency with freshening dominating at a rate of $29 \pm 50 \mathrm{~km}^{3} \mathrm{decade}^{-1}$.

- These FWC trends are modulated by strong multidecadal variability with sustained and widespread spatiotemporal patterns.

- Similar spatial patterns of anomalies in the upperlayer thickness, depth of the intermediate Atlantic Water core temperature, and SLP anomalies suggest a close connection between large-scale atmospheric circulation and Arctic oceanic conditions.

- The FWC anomalies generated on Arctic shelves (including river discharge inputs) and those caused by net atmospheric precipitation were too small to trig- ger long-term FWC variations in the central Arctic Ocean; on the contrary, they tend to moderate the observed long-term central-basin FWC changes.

- Variability of the intermediate AW did not have apparent impact on changes of the upper-Arctic Ocean water masses; and yet isopycnal heaving is an important component of variability of the natural layers of the upper Arctic Ocean.

- Ice production and sustained draining of freshwater from the Arctic Ocean in response to winds are the key contributors to the salinification of the upper Arctic Ocean over recent decades. Strength of the export of Arctic ice and water dominates the supply of Arctic freshwater to subpolar basins while the intensity of the Arctic Ocean FWC anomalies is of less importance. Further research is required to provide quantitative estimates of impacts freshwater export and ice production may have on high-latitude FWC changes.

In the broader view, we demonstrate a strikingly coherent pattern of long-term variations of the key Arctic climate parameters and strong coupling of long-term changes in the Arctic climate system with those at lower latitudes on large spatiotemporal scales. Figure 11 displays remarkably coherent low-frequency variations of the Arctic surface air temperature, Arctic Ocean FWC, and intermediate Atlantic Water core temperature, fastice thickness, and North Atlantic sea surface temperature. Elucidating the mechanisms behind this relationship will be critical to our understanding of the complex nature of low-frequency variability found in the Arctic and at lower latitudes and its impact on the climate change.

Acknowledgments. We thank U. Bhatt, S. Häkkinen, G. Holloway, V. Kattsov, and J. Walsh for useful discussions. The manuscript improved from the insightful comments of the three anonymous reviewers. This publication is the result of research sponsored by the Cooperative Institute for Arctic Research (CIFAR project 33-088) with funds from the NOAA under Cooperative Agreement NA17RJ1224 with the University of Alaska (IP, ID, and VI). IP and VI thank JAMSTEC and LT and GB thank the Russian Fund of Fundamental Research for financial support. MS is supported by the Office of Polar Programs, NSF and by the Cryospheric Sciences Program at NASA.

\section{APPENDIX A}

\section{Estimating Ice-Volume Changes}

An advanced assimilation technique based on NN and reverse-chronology algorithms is used to obtain re- 


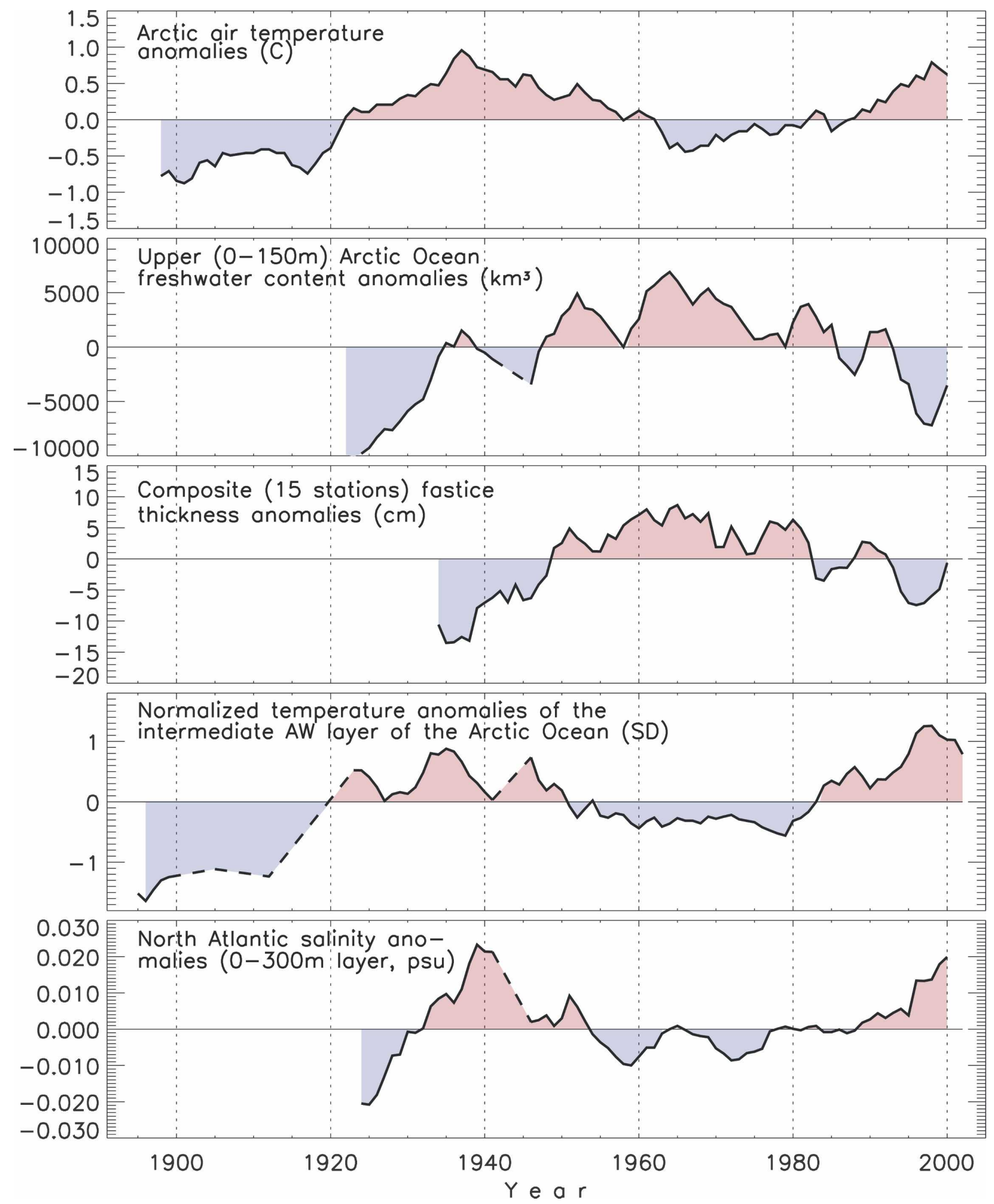

FIG. 11. Comparative long-term evolution of key components of the Arctic/North Atlantic climate system. Composite time series of 6-yr running mean anomalies of (from top to bottom) the Arctic surface air temperature (Polyakov et al. 2003a), upper 150-m Arctic Ocean FWC, fast ice thickness (Polyakov et al. 2003b), intermediate Atlantic Water core temperature of the Arctic Ocean (Polyakov et al. 2004), and upper 300-m North Atlantic water salinity (Polyakov et al. 2005) are shown. These time series show striking resemblance. 
liable spatiotemporal distributions of Arctic sea ice thickness using data from decades of satellite observations (Belchansky et al. 2008). This technique reconstructs monthly ice-thickness fields of the Arctic Ocean with adjacent Laptev, East Siberian, Chukchi, and Beaufort Seas using a 25-km resolution Special Sensor Microwave/Imager (SSM/I) polar stereographic grid. Our technique is based on the premise that the monthly ice thickness of any ice-covered grid cell results from its prehistory of combined effects of various dynamical and thermodynamical impacts the ice has experienced along its lifetime drift trajectory. Estimates of Arctic ice concentration (more information is available online at http://nsidc.org/data/docs/daac/nsidc0079_bootstrap seaice.gd.html), ice age (Belchansky et al. 2005b), and ice drift (Fowler 2003) derived from satellite imagery are used to define these ice-drift trajectories. The atmospheric thermodynamical forcing is specified via net short- and longwave radiation. An additional atmospheric parameter is provided by an empirical formula that relates freezing rate to the number of "freezing degree-days." This formula has been widely used in Russian Arctic research, and its thermodynamical justification is presented by Doronin (1970). Effects of ice dynamics are incorporated via ice-drift velocity and an ice divergence/convergence index, which is based on estimates of ice drift and is close to zero when ice conditions are divergent and about 1 when ice convergence is increased. These forcing parameters were chosen from many others (see discussion in appendix B).

Using available ice-thickness observations simultaneously with the forcing allows us to develop an effective assimilation $\mathrm{NN}$ algorithm and compute gridded ice thicknesses (Belchansky et al. 2004a, 2005a, 2008). Via a learning process based on available ice-thickness observations, the $\mathrm{NN}$ builds decision surfaces of any configuration from a wide class of functions without a priori assumptions about their distribution laws. Submarine ULS ice-draft profiles (Tucker et al. 1998) and ice-coring data from aircraft landing observations (ALO; Romanov 2004) were used as the NN learning and testing data. Estimates of the $\mathrm{NN}$ weight coefficients are obtained using the ULS dataset by assigning the median ice draft to the midpoint location of observational segments, and using the ALO drill hole dataset using prevailing ice type (without correction for hummocking).

Estimating high-order nonlinear relationships requires the $\mathrm{NN}$ to possess complex internal structure. Trial and error tests indicated that a three-layer perceptron without shortcut connections with 7-12-1 topology optimized NN complexity, computational efficiency, and ability to assimilate the learning data. Hid- den neurons have a logistic (sigmoid) activation function, input and output neurons have an identity activation function (i.e., input neurons pass their input values to hidden neurons without changes. The output of the output neuron is the weighted sum of its inputs and bias). We used a resilient propagation algorithm for the learning process. This algorithm prevents overfitting (Belchansky et al. 2008). Ten NNs were constructed by randomly splitting the learning data, using one half for learning and the other half for testing, and repeating the procedure 10 times. Monthly ice-thickness maps were created by accumulating the atmospheric forcing parameters along the drift tracks of each grid cell during its prehistory, using these cumulative forcing estimates as input to each of the $10 \mathrm{NNs}$, and averaging the 10 sea ice-thickness estimates.

For calculation of ice production as a contributor to salinity modification we used a module of a numerical Arctic Ocean model computing thermodynamical forcing for ice-free ocean and/or ice surfaces. This model was widely used for analysis of Arctic ice-ocean interactions (e.g., Polyakov and Johnson 2000; Johnson and Polyakov 2001). Using bulk formulas, the module diagnosed the net heat flux over open water driven by daily winds and air temperatures and other atmospheric parameters used in parameterized surface heat fluxes. National Centers for Environmental Prediction-National Center for Atmospheric Research (NCEP-NCAR) reanalysis provided daily surface air temperature and winds. Computed fluxes were then used to calculate equivalent ice thickness. Multiplied by ice-free area it produced an estimate of annual ice production and upper-ocean salinification shown in Fig. 10. The bulk of estimated salinification was due to an increase of icefree area (which explains $84 \%$ of its variance), but not to direct atmospheric forcing.

\section{APPENDIX B}

\section{Robustness of Analyses}

\section{a. Ice-volume NN-based assimilation technique}

Twenty-two parameters (including heat fluxes, SAT and SLP, wind speed, relative humidity, ice concentration, ice-drift velocity, and ice divergence/convergence) were tested as candidates for forcing. Stepwise regression analyses and network trials indicated that only those few described in appendix A yielded a methodologically stable and parsimonious subset. These parameters were used in the $\mathrm{NN}$ assimilation algorithm. Since the sea ice-thickness distribution function was not symmetrical, the $\mathrm{NN}$ learning and testing datasets included mean, median, and modal estimates of ice 
TABLE B1. Quality control for the NN-based ice-volume estimates

\begin{tabular}{|c|c|c|c|c|}
\hline & Region & $\begin{array}{c}\text { Mean } \\
\text { difference }\end{array}$ & $\begin{array}{l}\text { RMS } \\
\text { error }\end{array}$ & $\begin{array}{c}\text { Number of } \\
\text { observations }\end{array}$ \\
\hline \multicolumn{5}{|c|}{ Dependent learning data } \\
\hline ULS & Arctic Ocean & -0.01 & 0.53 & 2157 \\
\hline ALO & Extended shelf & 0.03 & 0.51 & 907 \\
\hline Combined & Arctic Ocean & 0.00 & 0.52 & 3064 \\
\hline $\begin{array}{l}\text { Rothrock et al. (1999) } \\
\text { Yu et al. (2004) }\end{array}$ & $\begin{array}{l}\text { Dependent regic } \\
\text { Arctic Ocean } \\
\text { Arctic Ocean }\end{array}$ & $\begin{array}{r}0.11 \\
-0.10\end{array}$ & $\begin{array}{l}0.42 \\
0.42\end{array}$ & $\begin{array}{l}15 \\
14\end{array}$ \\
\hline \multicolumn{5}{|c|}{ Independent samples (Haas and Eicken 2001) } \\
\hline Drill hole & Eastern Arctic & 0.18 & 0.90 & 147 \\
\hline Electromagnetic & Eastern Arctic & -0.10 & 0.54 & 67 \\
\hline $\begin{array}{l}\text { Cold Regions Research and } \\
\text { Engineering Laboratory }\end{array}$ & Beaufort Sea & 0.10 & 0.60 & 95 \\
\hline \multicolumn{5}{|c|}{ Independent stations } \\
\hline Moritz (2007) & North Pole & -0.24 & 0.43 & 13 \\
\hline Melling (2001) & Southeast Beaufort & 0.37 & 1.07 & 72 \\
\hline Melling et al. (2005) & Southeast Beaufort & 0.71 & 0.90 & 12 \\
\hline Vinje et al. (1998) & Fram Strait & 0.41 & 0.72 & 49 \\
\hline $\begin{array}{l}\text { More information is available online at } \\
\mathrm{http} / / \mathrm{nsidc} . \mathrm{org} / \mathrm{data} / \mathrm{g} 02139 . \mathrm{html}\end{array}$ & Fram Strait & -0.51 & 0.92 & 117 \\
\hline \multicolumn{5}{|c|}{ Independent maps } \\
\hline Løvås and Brude (1999) & Arctic Ocean & 0.16 & 0.62 & 104878 \\
\hline
\end{tabular}

thickness that were 2.64, 2.14, and $1.61 \mathrm{~m}$, respectively. Correlation coefficients between mean and median estimates is 0.97 [standard deviation $(\mathrm{SD})=0.26 \mathrm{~m}$ ], between mean and modal estimates is $0.85(\mathrm{SD}=0.49 \mathrm{~m})$, and between median and modal estimates is 0.91 ( $\mathrm{SD}=$ $0.29 \mathrm{~m}$ ). Since median estimates were "resistant" to the noise in the data, medians were used for NN learning and testing. An extensive comparison of the computed NN-based estimates of ice thickness with available observational data was performed (Table B1). We find that, in general, our estimates are computed quite accurately. However, there are rather wide uncertainty margins in ice-volume time series (Fig. 10) and a relatively high level of standard errors as seen from Table B1. The neural network estimates are similar to those obtained by conventional thermodynamic models (e.g., Rothrock et al. 2003). These errors may be attributed to uncertainties in atmospheric forcing; local estimates based on a few available observations may also increase the level of noise seen in the records. Note also that no in situ data have ever been collected at commensurate temporal and spatial scales that could be used to truly validate the NN monthly estimates for network's 625 $\mathrm{km}^{2}$ pixels.

\section{b. Testing robustness of the composite FWC anomalies}

A lack of observations places constraints on our ability to establish spatial and temporal patterns of long- term Arctic Ocean FWC variability. For example, the relatively short instrumental records make it difficult to infer firm, statistically sound conclusions about the exact time scales of multidecadal variability. The spatial coverage of available observational data rapidly deteriorates toward the earlier part of the twentieth century. Inadequate annual spatial coverage, even in the recent decades, may become a major obstacle for the understanding of mechanisms critical in the transition from one phase of multidecadal variability to another. It certainly has some impact on the computed annual anomalies presented by the composite FWC time series, which is expressed by widened uncertainty margins in the earlier parts of the records (Figs. 3 and 4). This may impact the estimates of magnitude of the FWC anomalies. Both the lack of observational data in the earlier part of the records and the large-amplitude multidecadal climate variability affecting the Arctic FWC changes may confound detection of the true underlying climate trend over the past century attributable to anthropogenic effects.

Despite the scarcity of observational data in the earlier part of the twentieth century, spatially and temporally averaged estimates presented in this study provide valuable insight into Arctic Ocean FWC variability. Four different groups of people were involved in processing oceanographic information and in independently composing FWC time series for different highlatitude regions (Figs. 3, 4, and 9). Consistent results 
attest about robustness of these composite time series. The striking resemblance between long-term variability of key Arctic and North Atlantic climate parameters (Fig. 11) also supports this conclusion.

Sensitivity of our regional statistical estimates presented in Table 1 to region size, location, and averaging procedure within each box measures the robustness of our analysis. For example, averaged over the 10 regions of the central Arctic Ocean, the standard error of estimating FWC mean and standard deviation for "standard" regions (Fig. 1) and for reduced-size regions (by approximately a half of their area) is about 0.03 and 0.02 , respectively. Statistical estimates based on different methods of calculating annual means within each region (simple spatial averaging versus distanceweighted averaging) do not differ significantly. The long-term FWC mean anomalies (red horizontal lines in Fig. 3) associated with the multidecadal peak values exceed the confidence intervals and thus are statistically significant; because of the large number of observations the error bars for these long-term mean anomalies are indistinguishable from the horizontal lines. Sensitivity of composite FWC anomaly time series for the Siberian marginal seas (Fig. 4) to grid resolution and radius of interpolation (used to build monthly and annual climatologies) was also evaluated. This analysis also shows robustness of the estimates for the FWC anomalies. For example, alternating the grid resolution within a wide range of $20-150 \mathrm{~km}$ resulted in highly correlated $(R>0.97)$ composite time series of the Laptev Sea FWC anomalies with standard deviations varying within $4 \%-13 \%$ only. A sensitivity analysis of the composite time series of upper ( $\sigma_{\theta}$ layer) Arctic Ocean FWC anomalies to the noise in the original data was measured. To estimate this, we added a random uniformly distributed noise to the original vertically integrated salinities. This random noise was calculated using three standard errors based on the entire set of salinities available for this layer. The resulting noisy composite time series were compared with the original time series calculating their correlation and SD. This process was repeated 1000 times and correlation was always $>0.99$ and the largest SD difference was $26 \mathrm{~km}^{3}$, suggesting that the FWC anomalies analyzed in this study cannot be attributed to random noise. We also estimated sensitivity of the composite time series of upper $\left(\sigma_{\theta}\right.$ layer) Arctic Ocean FWC anomalies to the choice of the mean referenced salinity [i.e., fixed 34.8 versus local climatological mean as suggested by Curry and Mauritzen (2005)]. Two composite time series were highly correlated $(R>0.99)$ with slightly $(\approx 6 \%)$ suppressed SD in case of the fixed salinity.

\section{REFERENCES}

Aagaard, K., and E. C. Carmack, 1989: The role of sea ice and other fresh water in the Arctic circulation. J. Geophys. Res., 94, 14 485-14 498.

_ tive. The Polar Oceans and Their Role in Shaping the Global Environment: The Nansen Centennial Volume, Geophys. Monogr., Vol. 85, Amer. Geophys. Union, 5-20.

—, E. Fahrbach, J. Meincke, and J. H. Swift, 1991: Saline outflow from the Arctic Ocean: Its contribution to the deep waters of the Greenland, Norwegian, and Iceland Seas. $J$. Geophys. Res., 96, 20 433-20 441.

ACIA, 2005: Arctic Climate Impact Assessment. Cambridge University Press, $1042 \mathrm{pp}$.

Belchansky, G. I., D. C. Douglas, I. V. Alpatsky, and N. G. Platonov, 2004a: Spatial and temporal multiyear sea ice distributions in the Arctic: A neural network analysis of SSM/I data, 1988-2001. J. Geophys. Res., 109, C10017, doi:10.1029/ 2004JC002388.

,-- , and N. G. Platonov, 2004b: Duration of the Arctic sea ice melt season: Regional and interannual variability, 19792001. J. Climate, 17, 67-80.

,,-- V. A. Eremeev, and N. G. Platonov, 2005a: Variations in the Arctic's multiyear sea ice cover: A neural network analysis of SMMR-SSM/I data, 1979-2004. Geophys. Res. Lett., 32, L09605, doi:10.1029/2005GL022395.

$[,-$, and N. G. Platonov, 2005b: Spatial and temporal variations in the age structure of Arctic sea ice. Geophys. Res. Lett., 32, L18504, doi:10.1029/2005GL023976.

,-- , and - 2008: Fluctuating Arctic sea ice thickness changes estimated by an in situ learned and empirically forced neural network model. J. Climate, in press.

Carmack, E. C., and Coauthors, 1997: Changes in temperature and tracer distributions within the Arctic Ocean: Results from the 1994 Arctic Ocean section. Deep-Sea Res. II, 44, $1487-1502$.

Comiso, J. C., 2003: Warming trends in the Arctic from clear sky satellite observations. J. Climate, 16, 3498-3510.

Curry, R., and C. Mauritzen, 2005: Dilution of the northern North Atlantic Ocean in recent decades. Science, 308, 1772-1773.

Delworth, T. L., and M. E. Mann, 2000: Observed and simulated multidecadal variability in the Northern Hemisphere. Climate Dyn., 16, 661-676.

Dickson, R. R., 1999: All change in the Arctic. Nature, 397, 389391.

, and Coauthors, 2000: The Arctic Ocean response to the North Atlantic Oscillation. J. Climate, 13, 2671-2696.

—, I. Yashayaev, J. Meincke, W. R. Turrell, S. Dye, and J. Holfort, 2002: Rapid freshening of the deep North Atlantic Ocean over the past four decades. Nature, 416, 832-837.

Doronin, Yu. P., 1970: Thermal Interaction of the Atmosphere and the Hydrosphere in the Arctic. E. P. Borisenkov, Ed., Israel Program for Scientific Translations, 244 pp. (Translated from Russian by D. Lederman.)

Fowler, C., 2003: Polar Pathfinder daily 25 km EASE-Grid sea ice motion vectors. National Snow and Ice Data Center, Boulder, CO, digital media. [Available online at http://nsidc.org/ data/nsidc-0116.html.]

Gorshkov, S. G., 1980: Atlas of Oceans: Arctic Ocean (in Russian). Military Defense Publishing House, 199 pp.

Haas, C., and H. Eicken, 2001: Interannual variability of summer sea ice thickness in the Siberian and central Arctic under 
different atmospheric circulation regimes. J. Geophys. Res., 106, 4449-4462.

Häkkinen, S., and A. Proshutinsky, 2004: Freshwater content variability in the Arctic Ocean. J. Geophys. Res., 109, C03051, doi:10.1029/2003JC001940.

Houghton, J. T., Y. Ding, D. J. Griggs, M. Noguer, P. J. van der Linden, X. Dai, K. Maskell, and C. A. Johnson, Eds., 2001: Climate Change 2001: The Scientific Basis. Cambridge University Press, $881 \mathrm{pp}$.

Johnson, M. A., and I. V. Polyakov, 2001: The Laptev Sea as a source for recent Arctic Ocean salinity changes. Geophys. Res. Lett., 28, 2017-2020.

Lindsay, R. W., and J. Zhang, 2005: The thinning of Arctic sea ice, 1988-2003: Have we passed a tipping point? J. Climate, 18, 4879-4894.

Løvås, S. M., and O. W. Brude, 1999: INSROP GIS-Software and database. Fridtjof Nansen Institute and Central Marine Research and Design Institute, Working Paper 47-1996.

Maslowski, W., D. C. Marble, W. Walczowski, and A. J. Semtner, 2001: On large scale shifts in the Arctic Ocean and sea ice conditions during 1979-1998. Ann. Glaciol., 33, 545-550.

Matishov, G., A. Zyev, V. Golubev, N. Adrov, V. Slobidin, S. Levitus, and I. Smolyar, 1998: Climatic Atlas of the Barents Sea 1998: Temperature, Salinity, Oxygen. NOAA Atlas NESDIS 26, 25 pp.

Mauritzen, C., and S. Häkkinen, 1997: Influence of the sea ice on the thermohaline circulation in the North Atlantic Ocean. Geophys. Res. Lett., 24, 3257-3260.

Melling, H., 2001: Is the extent or thickness of Arctic sea ice declining? The State of the Arctic Cryosphere during the Extreme Warm Summer of 1998: Documenting Cryospheric Variability in the Canadian Arctic, CCAF summer 1998 Project Team Final Rep.

— D. A. Reidel, and Z. Gedalof, 2005: Trends in the draft and extent of seasonal pack ice, Canadian Beaufort Sea. Geophys. Res. Lett., 32, L24501, doi:10.1029/2005GL024483.

Morison, J., K. Aagaard, and M. Steele, 2000: Recent environmental changes in the Arctic: A review. Arctic, 53, 359-371.

Moritz, R. E., 2007: Variability of sea-ice draft near the North Pole on time scales of 1 week to 2 years. J. Geophys. Res., in press.

Muench, R. D., M. G. McPhee, C. A. Paulson, and J. H. Morrison, 1992: Winter oceanographic conditions in the Fram Strait Yermak Plateau region. J. Geophys. Res., 97, 3469-3483.

Mysak, L. A., D. K. Manak, and R. F. Marsden, 1990: Sea-ice anomalies observed in the Greenland and Labrador seas during 1901-1984 and their relation to an interdecadal Arctic climate cycle. Climate Dyn., 5, 111-133.

Overland, J. E., M. C. Spillane, and N. N. Soreide, 2004: Integrated analysis of physical and biological pan-Arctic change. Climatic Change, 63, 291-322.

Peterson, B., J. McClelland, M. Holmes, R. Curry, J. Walsh, and K. Aagaard, 2006: Acceleration of the Arctic and Subarctic freshwater cycle. Science, 313, 1061-1066.

Polyakov, I. V., and M. A. Johnson, 2000: Arctic decadal and interdecadal variability. Geophys. Res. Lett., 27, 4097-4100.

— , R. V. Bekryaev, G. V. Alekseev, U. Bhatt, R. L. Colony, M. A. Johnson, A. P. Makshtas, and D. Walsh, 2003a: Variability and trends of air temperature and pressure in the maritime Arctic, 1875-2000. J. Climate, 16, 2067-2077.

- and Coauthors, 2003b: Long-term ice variability in arctic marginal seas. J. Climate, 16, 2078-2085.

- and Coauthors, 2004: Variability of the intermediate Atlan- tic water of the Arctic Ocean over the last 100 years. J. Climate, 17, 4485-4497.

, U. S. Bhatt, H. L. Simmons, D. Walsh, J. E. Walsh, and X. Zhang, 2005: Multidecadal variability of North Atlantic temperature and salinity during the twentieth century. J. Climate, 18, 4562-4581.

— , and Coauthors, 2007: Observational program tracks Arctic Ocean transition to a warmer state. Eos, Trans. Amer. Geophys. Union, 88, 398-399.

Proshutinsky, A., R. H. Bourke, and F. A. McLaughlin, 2002: The role of the Beaufort Gyre in Arctic climate variability: Seasonal to decadal climate scales. Geophys. Res. Lett., 29, 2100, doi:10.1029/2002GL015847.

_ I. M. Ashik, E. N. Dvorkin, S. Häkkinen, R. A. Krishfield, and W. R. Peltier, 2004: Secular sea level change in the Russian sector of the Arctic Ocean. J. Geophys. Res., 109, C03042, doi:10.1029/2003JC002007.

Reverdin, G., D. Cayan, and Y. Kushnir, 1997: Decadal variability of hydrography in the upper northern North Atlantic in 1948-1990. J. Geophys. Res., 102, (C4), 8505-8532.

Rigor, I. G., and J. M. Wallace, 2004: Variation in the age of Arctic sea-ice and summer sea-ice extent. Geophys. Res. Lett., 31, L09401, doi:10.1029/2004GL019492.

— - _ and R. L. Colony, 2002: Response of sea ice to the Arctic Oscillation. J. Climate, 15, 2648-2663.

Romanov, I. P., 2004: Morphometric characteristics of ice and snow in the Arctic Basin: Aircraft landing observations from the Former Soviet Union, 1928-1989. National Snow and Ice Data Center, Boulder, CO, digital media. [Available online at http://nsidc.org/data/g02140.html.]

Rothrock, D. A., and J. Zhang, 2005: Arctic Ocean sea ice volume: What explains its recent depletion? J. Geophys. Res., 110, C01002, doi:10.1029/2004JC002282.

_ , Y. Yu, and G. A. Maykut, 1999: Thinning of the Arctic sea-ice cover. Geophys. Res. Lett., 26, 3469-3472.

_ - J. Zhang, and Y. Yu, 2003: The arctic ice thickness anomaly of the 1990s: A consistent view from observations and models. J. Geophys. Res., 108, 3083, doi:10.1029/2001JC001208.

Rudels, B., G. Björk, J. Nilsson, P. Winsor, I. Lake, and C. Nohr, 2005: The interaction between water from the Arctic Ocean and the Nordic Seas north of Fram Strait and along the East Greenland Current: Results from the Arctic Ocean-02 Oden expedition. J. Mar. Syst., 55, 1-30.

Serreze, M. C., and Coauthors, 2000: Observational evidence of recent change in the northern high-latitude environment. Climatic Change, 46, 159-207.

- , and Coauthors, 2003: A record minimum arctic sea ice extent and area in 2002. Geophys. Res. Lett., 30, 1110, doi:10.1029/2002GL016406.

Smith, D. M., 1998: Recent increase in the length of the melt season of perennial arctic sea ice. Geophys. Res. Lett., 25, $655-658$.

Steele, M., and T. Boyd, 1998: Retreat of the cold halocline layer in the Arctic Ocean. J. Geophys. Res., 103, 10 419-10 435.

__ , and W. Ermold, 2005: Salinity trends on the Siberian shelves. Geophys. Res. Lett., 31, L24308, doi:10.1029/ 2004GL021302.

_ and - 2007: Steric sea level change in the Northern Seas. J. Climate, 20, 403-417.

Stroeve, J. C., M. C. Serreze, F. Fetterer, T. Arbetter, W. Meier, J. Maslanik, and K. Knowles, 2005: Tracking the Arctic's shrinking ice cover: Another extreme September minimum in 
2004. Geophys. Res. Lett., 32, L04501, doi:10.1029/ 2004GL021810.

Swift, J. H., 1986: The Arctic waters. Nordic Seas, B. G. Hurdle, Ed., Springer-Verlag, 129-153.

- E. P. Jones, K. Aagaard, E. C. Carmack, M. Hingston, R. W. MacDonald, F. A. McLaughlin, and R. G. Perkin, 1997: Waters of the Makarov and Canada basins. Deep-Sea Res., 44, $1503-1529$.

-, K. Aagaard, L. Timokhov, and E. G. Nikiforov, 2005: Longterm variability of Arctic Ocean waters: Evidence from a reanalysis of the EWG data set. J. Geophys. Res., 110, C03012, doi:10.1029/2004JC002312.

Tucker, W. B., III, and Coauthors, 1998: Submarine upward looking sonar ice draft profile data and statistics. National Snow and Ice Data Center, Boulder, CO, digital media. [Available online at http://nsidc.org/data/g01360.html.]

Venegas, S. A., and L. A. Mysak, 2000: Is there a dominant timescale of natural climate variability in the Arctic? J. Climate, 13, 3412-3434.
Vinje, T., N. Norland, and A. Kvambekk, 1998: Monitoring ice thickness in Fram Strait. J. Geophys. Res., 103, $10437-10449$.

Woodgate, R. A., E. Fahrbach, and G. Rohardt, 1999: Structure and transport of the East Greenland Current at $75^{\circ} \mathrm{N}$ from moored current meters. J. Geophys. Res., 104, 18 059-18 072.

_, K. Aagaard, and T. J. Weingartner, 2005: Monthly temperature, salinity, and transport variability of the Bering Strait through flow. Geophys. Res. Lett., 32, L04601, doi:10.1029/ 2004GL021880.

Yi, D., L. A. Mysak, and S. A. Venegas, 1999: Decadal-tointerdecadal fluctuations of Arctic sea-ice cover and the atmospheric circulation during 1954-1994. Atmos.-Ocean, 37, 389-415.

Yu, Y., G. A. Maykut, and D. A. Rothrock, 2004: Changes in the thickness distribution of Arctic sea ice between 1958-1970 and 1993-1997. J. Geophys. Res., 109, C08004, doi:10.1029/ 2003JC001982.

Zhang, J., D. A. Rothrock, and M. Steele, 1998: Warming of the Arctic Ocean by a strengthened Atlantic inflow: Model results. Geophys. Res. Lett., 25, 1745-1748. 